\title{
The Glass Ceiling: Potential Causes and Possible Solutions
}

Beverly A. Dugan, Jessica L. Terner, Felicity A. Tagliarini, J. Anthony Bayless, and Helene R. Felber Human Resources Research Organization

Carlos K. Rigby and Steve Kronheim U.S. Army Research Institute

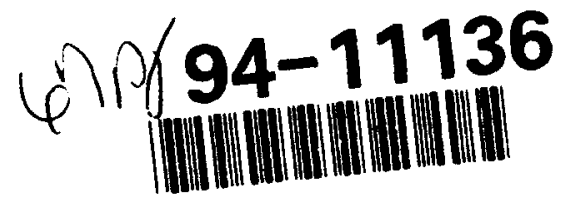

December 1993

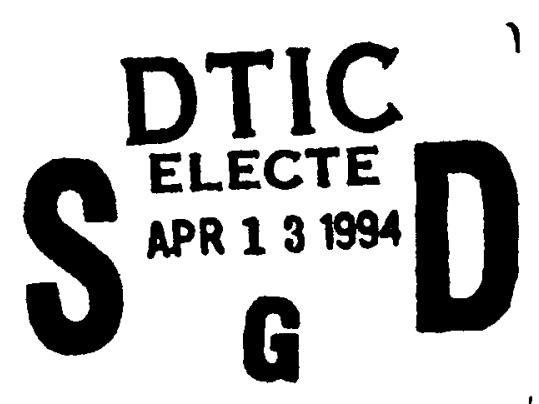

$$
94 \quad 4 \quad 12 \quad 066
$$

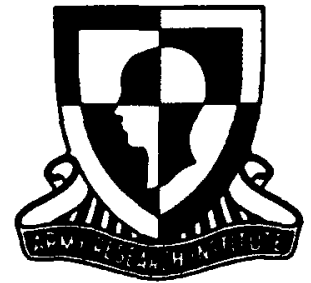

United States Army Research Institute for the Behavioral and Social Sciences

$$
\text { Das }
$$




\title{
U.S. ARMY RESEARCH INSTITUTE \\ FOR THE BEHAVIORAL AND SOCIAL SCIENCES
}

\author{
A Field Operating Agency Under the Jurisdiction \\ of the Deputy Chief of Stafif for Personnel
}

EDGAR M. JOHNSON

Director

Research accomplished under contract

for the Department of the Army

Human Resources Research Organization

Technical review by

Nijole Benekraitus , University of Maryland, Baltimor_ Campus T.O. Jacobs

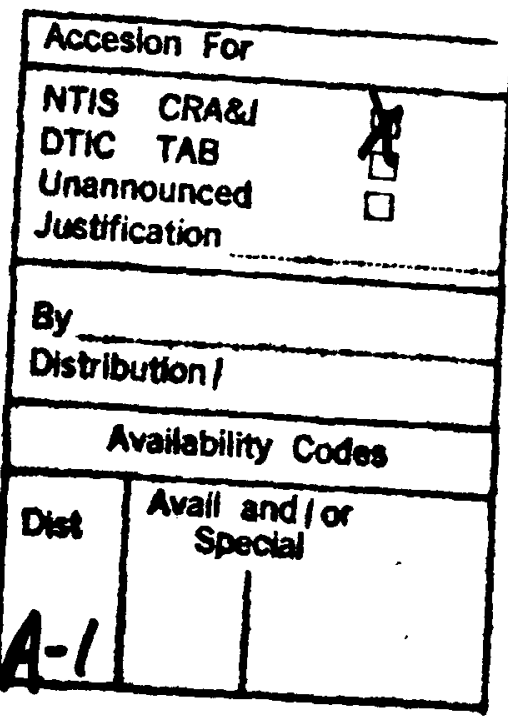

VTR QUWLTTY LUETECTED 3

\section{NOTCES}

DISTRIBUTION: Primary distribution of this repon has been made by ARI. Please address correspondence conceming distribution of reports to: U.S. Army Research Institute for the Behavioral and Social Sciences, ATTN: PERI-POX, 5001 Eisenhower Ave., Alexandria, Virginia 22333-5600.

FINAL DISPOSIrTON: This report may be destroyed when it is no longer needed. Please do not return it to the U.S. Army Research Institute for the Behavioral and Social Sciences.

NOrt: The findings in this report are not to be construed as an official Department of the Amy position, unless so designated by other authorized documents. 


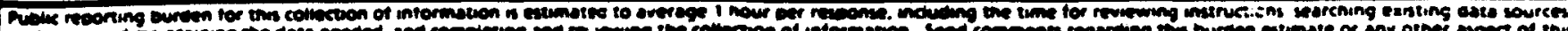

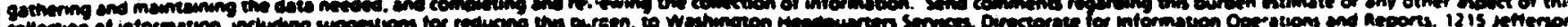

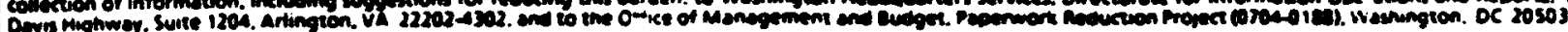

1. AGENCY USE ONIY (LeAve ount) 2. REPOAT DATE

1993, December $\quad$ Final

DATES COVERED

\section{IITLE AND SUOTITLE}

The Glass Celling: Potential Causes and Possible Solutions

6. AUThon(s) Dugan, Beverly A。; Terner, Jessica L.; Tagllarini, Felicity A.; Bayless, J. Anthony; Felber, Helene R. (HumRRO); Rigby, Carlos K.; and Kronheim, Steve (ARI)

7. PERFORMING ORGANIZATION MAME(S) AMD ADORESS(ES)

Human Resources Research Organization

66 Canal Center Plaza, Suite 400

Alexandria, VA 22314

9. SPONSORING /MONITORING AGENCY MAME(S) AND ADDRESS(ES)

U.S. Army Research Institute for the Behavioral and

Social Sciences

ATTN: PERI-RO

5001 Eisenhower Avenue

Alexandria, VA 22333-5600

11. SUPPLEMENTARY NOTES

Contracting Officer's Representative, Carlos K. Rigby.
Nov 92 - Jul 93

5. FUNONG MUMEERS

MA903-87-C-0846

63007A

792

1112

120. DISTRIBUTION /AVALABUITY STATEMEAT

Approved for public release;

distribution is unlimited.

12b. OSTRISUTION CODE

10. SPONSORING / MONITORING AGENCY REPORT NUMAER

ARI Technical Report 993

\section{ABSTRACT (Maxumum 200 words)}

Identifying barriers to advancement in its civilian workforce for women; minorities, and the disabled is a continuing concern for the Department of the Army. This literature review focuses on three potential causes of underrepresentation of minorities and women in the management ranks; lack of data on the disabled precluded treatment of this subgroup. The three causes of underrepresentation are systemic barriers, stereotypes and biases, and group differences. Systemic barriers are widespread policies and practices that perpetuate discriminatory treatment. Stereotypes and biases are thought to underlie the belief that minorities and women are not suited for managerial jobs. Indivitual factors and group differences refer to the extent to which individual deficiencies, common to members of a subgroup, are responsible for underrepresentation of women and minorities in the management ranks. Based on findings in the literature, the report suggests avenues for future research on barriers to advancement within the Army and highlights methods that might reduce such barriers.

\section{SUafect Tenms}

Army

Civilian management

Supervisor
17. SECUNTY aASSIFICATIOM OP nepont

Unclassified
Glass ceiling

Affirmative action
15. NUMBEA OF PAGES 67

16. mine COOE
10. SCCUMTY QASSHFKATION of Twis Dage Unclassified
19. SECUTIY QASSTHCATIOM of Aostmact Unclassified
20. LnmTation of anstact Unlimited 


\title{
The Glass Ceiling: Potential Causes and Possible Solutions
}

\author{
Beverly A. Dugan, Jessica L. Terner, Felicity A. Tagliarini, \\ J. Anthony Bayless, and Helene R. Felber \\ Human Resources Research Organization \\ Carlos K. Rigby and Steve Kronheim \\ U.S. Army Research Institute
}
Strategic Leadership Technical Area
T.O. Jacobs, Chief

Manpower and Personnel Research Division Zita M. Simutis, Director

U.S. Army Research Institute for the Behavioral and Social Sciences 5001 Eisenhower Avenue, Alexandria, Virginia 22333-5600

Office, Deputy Chief of Staff for Personnel

Department of the Army

\section{December 1993}


A recent review of the Senior Executive Service (SES) program in the Department of the Army concluded that more attention is needed in preparing candidates at grades 13, 14, and 15 for SES appointment. The review also concluded that the representation of women and minorities is disproportionately small at higher management levels. To explore possible reasons for this result, the Army has initiated a study of the "glass ceiling." The glass ceiling is an invisible barrier based on attitudinal and organizational bias that prevents minorities, women, and persons with disabilities from advancing into mid-and senior-level management positions.

The Deputy Assistant Secretary, Military Personnel Management and Equal Opportunity Policy, requested that the U.S. Army Research Institute for the Behavioral and Social Sciences (ARI) conduct a literature review to identify potential causes of the glass ceiling and promising empirical approaches for investigating it. The literature review will serve as a framework for further investigations.

The U.S. Army Research Institute's participation in this effort is part of an ongoing research program designed to enhance the quality of Army personnel. The Civilian Leadership Research Program was established to improve the leadership of Army civilians. This work is an essential part of the mission of ARI's Manpower and Personnel Research Division to improve the leadership effectiveness of the Army's workforce.

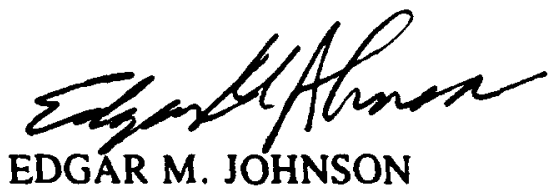

Director 


\section{ACKNOWLEDGMENTS}

The authors wish to thank Nikki Bellamy and Donna Angle of the U.S. Army Research Institute for the Behavioral and Social Sciences (ARI) for their assistance in the early stages of this effort. We also want to thank $T$. Owen Jacobs for an insightful and thought-provoking review of an earlier draft of this report. 
THE GLASS CEILING: POTENTIAL CAUSES AND POSSIBLE SOLUTIONS

EXECUTTVE SUMMARY

Requirement:

The Department of the Army wishes to initiate a glass ceiling study to identify barriers to advancement for women, minorities, and the disabled in its civilian workforce. As a first step in this study, the U.S. Army Research Institute for the Behavioral and Social Sciences was tasked to survey the glass ceiling literature for the Deputy Assistant Secretary, Military Personnel Management and Equal Opportunity Policy. This report is the product of that literature review.

Procedure:

The literature review focused on three potential causes of the glass ceiling: systemic barriers; stereotypes and biases; and individual factors and group differences. Systemic barriers are widespread policies and practices, both formal and informal, that perpetuate discriminatory treatment of women and minorities. Stereotypes and biases are thought to underlie the belief that minorities and women are not suited for managerial jobs. Individual factors and group differences refer to the extent to which individual deficiencies, common to members of a subgroup, are largely responsible for the underrepresentation of women and minorities in the management ranks.

Findings:

Systemic Barriers. Men tend to hold more powerful positions with higher levels of responsibility and authority than women. Confinement to lower level, staff, or dead-end jobs may promote management style and behavior that are viewed as ineffective, further reducing possibilities for advancement. Compounding the historical trend is the apparent reluctance of white male managers to give women and minorities highly visible, challenging assignments, thus denying them the types of experiences that promote the development of managerial and executive talent. 
There is some evidence that women and minorities are excluded from informal networks that provide the information, feedback, and contacts necessary for career advancement. Research also suggests that minorities and women have more difficulty finding a mentor than do white males. Moreover, mixed-gender mentorships pose potential problems in establishing a relationship that is supportive of a female manager's development.

Attitudinal research indicates that distinct differences in perceptions exist among gender and racial/ethnic groups regarding the extent to which systemic barriers exist. Women and minorities identify attitudinal and cultural barriers to promotion, whereas white men are more likely to feel that structure changes have eliminated those barriers. White males seem to see fewer obstacles to opportunity sharing than do women and minorities. They are more likely to think that a system in which employee treatment was based on merit has been replaced with one in which women and minorities are favored because of affirmative action.

Stereotypes and Biases. A natural tendency to categorize and stereotype people who are different exists. Beliefs about behavioral requirements for success in traditionally maledominated roles such as that of manager reflect the gender role stereotype of the male. Stereotypically female behavior patterns are deemed inconsistent with the model of the successful manager. The perceived lack of fit between the female's category and her managerial occupation may place a woman in a cruel bind. The prescriptive stereotype dictating that a woman should be, for example, passive and sensitive conflicts with the model of the successful manager, who should be competitive and independent.

When criteria are ambiguous and information about the individual is limited, stereotypes can provide structure and meaning, thereby influencing performance evaluations. Familiarity with the individual being evaluated, specific job-related performance criteria developed to minimize subjectivity and bias, and training in evaluation procedures are among the contextual factors that may override stereotypes.

Individual Factors and Group Differences. Several subgroup differences that potentially contribute to the underrepresentation of women in higher management and executive levels were researched. Disparities in the proportion of whites and minorities may be exacerbated when hiring and promotion decisions are based on tests that measure cognitive abilities. The use of supervisory and managerial selection tests that have little or no adverse impact should minimize the influence of differences in performance on employment screens.

Experience, education, tenure, willingness to relocate, and commitment to the job are all highly related to advancement. However, when these factors are held constant across males and females, females still tend to lag behind males in organizational level and pay.

Women tend to be less willing to relocate than men, and reluctance to relocate is perceived as demonstrating a lack of commitment. Attitudinal measures suggest, however, 
that women do not differ from men on job satisfaction, job commitment, and ambition. Nevertheless, women may be deemed less committed than men, regardless of family responsibilities, and this misperception may reduce opportunity for advancement.

Women seem to view pay differently than men. Although women and men value high pay equally, the lower self-pay expectations of women at career entry and career peak are related to greater child-care responsibilities. Different pay expectations may contribute to the finding that with all else equal, women are still paid less than men. To the extent that women communicate lower pay expectations to prospective employers, they may actually receive lower pay than men for equivalent work.

\section{Utilization of Findings:}

The final section of the report presents two types of recommendations: one suggests promising avenues for research for the Army's investigation of the glass ceiling; the other lists actions that organizations might take to reduce barriers to advancement for minorities and women. This report has been provided to the Deputy Assistant Secretary, Military Personnel Management and Equal Opportunity Policy, to assist in the planning of the follow-on study effort. It should be useful in three ways. First, it will help to identify the most productive approaches to follow in the empirical study. Second, it will provide a research-based context to assist with the interpretation of the Army's results. Finally, the report highlights promising methods for overcoming or limiting barriers to advancement for women and minorities. 
THE GLASS CEILING: POTENTIAL CAUSES AND POSSIBLE SOLUTIONS

CONTENTS

Page

INTRODUCTION $\ldots \ldots \ldots \ldots \ldots \ldots \ldots \ldots \ldots \ldots \ldots \ldots$

The Problem $\ldots \ldots \ldots \ldots \ldots \ldots \ldots \ldots \ldots \ldots \ldots \ldots \ldots$

Objectives and Limitations of the Study $\ldots \ldots \ldots \ldots \ldots \ldots \ldots \ldots \ldots$

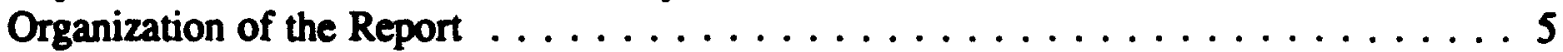

SYSTEMIC BARRIERS $\ldots \ldots \ldots \ldots \ldots \ldots \ldots \ldots \ldots \ldots \ldots$

Introduction . . . . . . . . . . . . . . .

Power, Authority, and Responsibility . . . . . . . . . . . . 7

Behavioral and Attitudinal Implications of Power Differences . . . . . . . . 9

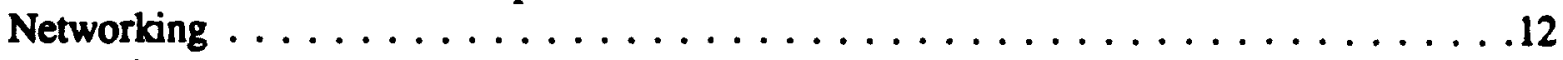

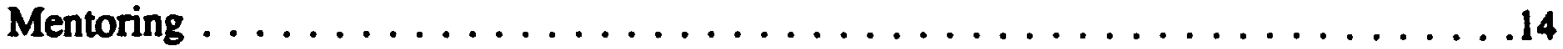

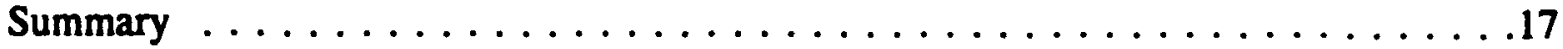

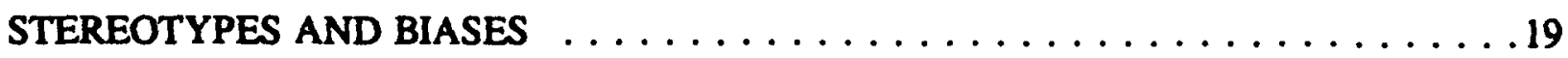

Gender-Specific Performance Expectations . . . . . . . . . . . . . . . . 19

Performance Evaluations and Stereotyping $\ldots \ldots \ldots \ldots \ldots \ldots \ldots \ldots \ldots \ldots \ldots \ldots$

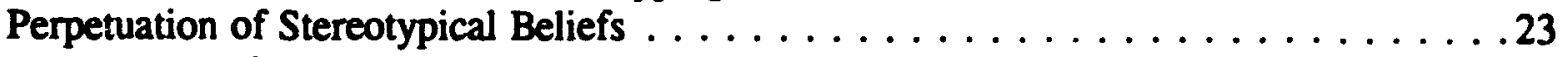

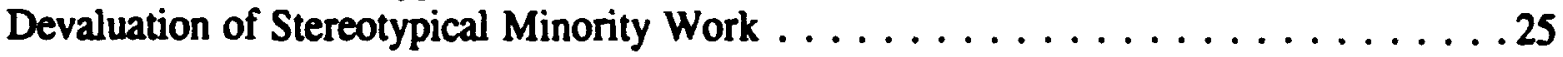

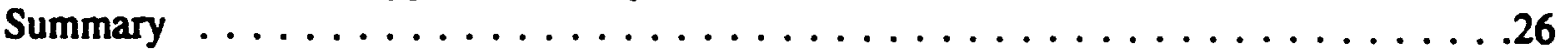

INDIVIDUAL FACTORS AND GROUP DIFFERENCES $\ldots \ldots \ldots \ldots \ldots$

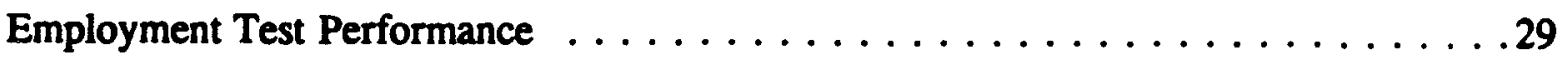

Human Capital . . . . . . . . . . . . . . . . . . . . . . .

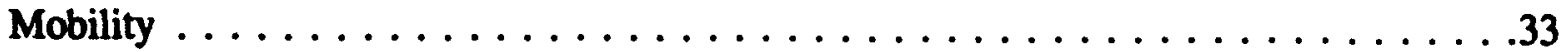

Family Care Responsibilities . . . . . . . . . . . . . . . . 35

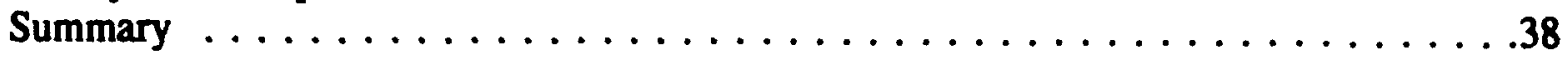


CONCLUSIONS AND RECOMMENDATIONS $\ldots \ldots \ldots \ldots \ldots \ldots \ldots \ldots \ldots$

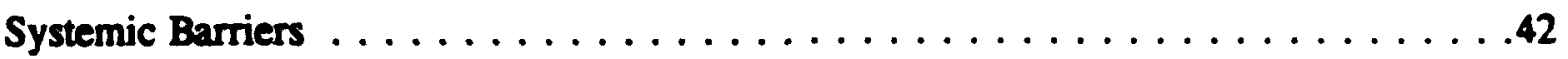

Stereotypes and Biases . . . . . . . . . . . . . . . . . . 45

Individual Factors and Group Differences $\ldots \ldots \ldots \ldots \ldots \ldots \ldots \ldots$

Planning Considerations . . . . . . . . . . . . . . . .

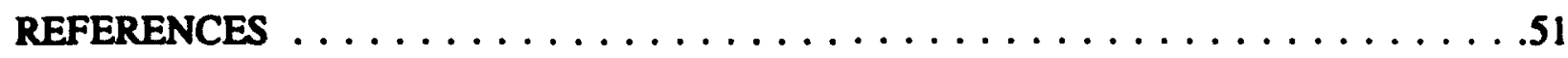

APPENDIX A. HIGHLIGHTS OF CIVIL RIGHTS LEGISLATION AND

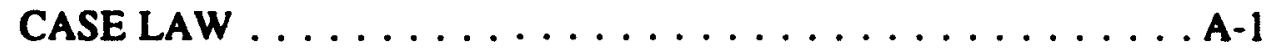




\section{THE GLASS CEILING: POTENTIAL CAUSES AND POSSIBLE SOLUTIONS}

\section{INTRODUCTION}

There is now considerable evidence that barriers exist preventing women and minorities from advancing in corporations. The "glass ceiling," a term popularized in the 1980s by Ann Morrison and others at the Center for Creative Leadership, originally referred to barriers to advancement for women. Since the term was established, its meaning has evolved to include barriers to advancement for all underrepresented groups. It is considered to be a "barrier so subtle that it is transparent, yet so strong that it prevents women and minorities from moving up in the management hierarchy" (Morrison \& Von Glinow, 1990, p. 200).

The identification of barriers to advancement for women, minorities, and the disabled in its civilian workforce is a continuing concern for the Department of the Army. To initiate a comprehensive study on this topic, the Deputy Assistant Secretary, Military Personnel Management and Equal Opportunity Policy, tasked the U.S. Army Research Institute for the Behavioral and Social Sciences to survey the glass ceiling literature. This report is the product of that literature review.

\section{The Problem}

For almost 30 years, legislation has required that Federal agencies provide equal employment opportunity. The Civil Rights Act (as amended by the Equal Employment Opportunity Act of 1972) requires agencies to develop and implement affirmative employment programs to counter the historical underrepresentation of certain subgroups in the workforce. The Equal Employment Opportunity Commission is charged with providing guidance to agencies on developing affirmative employment programs and with approving plans for such programs (General Accounting Office, 1991).

The Civil Service Reform Act of 1978 requires that Federal personnel management practices supply a competent, honest, and productive workforce that reflects the nation's diverse population. This act also requires agencies to conduct affirmative recruitment programs in occupations in which women and minorities are underrepresented. The Office of Personnel Management (OPM) was given responsibility for assisting agencies in their affirmative recruitment efforts and for overseeing the Federal Equal Opportunity Recruitment Program (General Accounting Office, 1991).

The Civil Rights Act of 1991 constitutes the first large scale effort by the government to examine the barriers faced by women and minorities. Title II of this Act, named the Glass Ceiling Act, has two main purposes: to establish a Glass Ceiling Commission that will terminate in 1995, and to establish an annual award for excellence in promoting a more diverse skilled workforce at higher levels. The purposes of the Glass Ceiling Commission are to focus greater attention on the importance of eliminating artificial barriers to the advancement of women and minorities to management and decision-making positions and to promote workforce diversity. The Commission, chaired by the Labor Secretary, is required to examine employers' practices and policies regarding opportunities for 
advancement for women and minorities and to recommend actions to correct deficiencies. Although the Glass Ceiling Act does not itself generate change in legislation, it is part of the 1991 Civil Rights Act which does generate legislative change in regard to recent case law.'

Various studies have noted improvements in the employment of women and minorities over the years. For example, the General Accounting Office (GAO, 1991) reported that, except for black and American Indian men, employment levels for minorities and women were higher in 1990 than 1982 . The employment level for black men dropped .5 percent and that for American Indian men remained unchanged.

While women and minorities have begun to climb the corporate ladder, their proportional presence in high level and high paying positions does not approach that of white males. For example, the Department of Labor (1991) found that while 37 percent of employees in the nine surveyed Federal contractors are female, only 17 percent of management positions are held by women and only 6.6 percent of all executives are women. The numbers show an even greater discrepancy for minorities. Fifteen and one-half percent of all employees are minority group members, yet minorities hold only 6 percent of all management positions and only 2.6 percent of all executive positions. The DOL results showed that there is a point beyond which women and minorities simply have not advanced (minorities plateau at an even lower level than women). Another study conducted with 400 Fortune 1000 companies found that less than 9 percent of all managers were minorities (cited in Morrison \& Von Glinow, 1990).

The second Department of Labor (1992) report on the Glass Ceiling Initiative indicated that while progress is being made, many barriers to top positions still exist. The study found that while women and minorities are hired at entry levels, hiring practices do not extend to the recruitment of a diverse pool of applicants at higher levels. In addition, the report revealed a lack of commitment to diversity among top managers despite mention of increased interest in diversity. That is, the willingness to take action to ensure that diversity exists at all levels of the corporate world was not generally apparent. Thus, success stories of qualified minorities and women advancing into higher level management positions were the exception rather than the rule.

The GAO actually found that getting to the top might be easier for women and minorities in the Federal government than it is in the private sector. As of September 30, 1990, women and minorities made up 17.2 percent of the Federal Senior Executive Service workforce, but occupied only 9.2 percent of the executive level positions in the 94 Fortune 1000 companies surveyed by the Department of Labor in the 1991 glass ceiling report (GAO, 1991). However, in this same study, the GAO examined the distribution of women and minorities across 261 key jobs in 25 agencies. Key jobs are jobs that can lead to middle and upper management positions. The study found that not only were white women and minorities more likely to be employed in jobs that were not "key," but also that they were often underrepresented in key jobs in relation to their representation in the civilian labor force

${ }^{1}$ The interested reader will find in the appendix a more detailed description of major civil rights legislation and case law since passage of the first Civil Rights Act of 1964. 
for the same occupations. In addition, women and minorities who held key jobs were much more likely to be found in the lower grades than in grades 12 through 15 .

A lirge-scale survey conducted by the U.S. Merit Systems Protection Board (MSPB) in $1992^{2}$ found that barriers to top-level Federal government jobs exist for women, even when they are equivalent to men in education, experience, job performance, and job commitment. Nearly 50 percent of white-collar Federal executive branch jobs are held by women, yet only 25 percent of supervisors and only 11 percent of executives are female. Minority women and women with children were found to be promoted at an even lower rate than their white and childless female counterparts.

The MSPB developed a mathematical forecasting model to estimate the rate at which the composition of the Federal workforce can be expected to change over the next 25 years. Their model included the effects of average hiring, separation, retirement, transfer, and promotion rates among occupational categories over two 3-year periods: fiscal years 19781980 and 1988-1990. It assumed that $1988-90$ rates would hold for the next 25 years. They found that women were entering Professional and Administrative occupations (the occupations that feed upper management levels) at a much greater rate in the late 1980's than in the previous time period, and that the average rate of employees leaving Government grew over the decade. As a result, the opportunity for women to move into and up through the pipeline is significantly greater now than it was in 1978-80. The model showed that the percentage of women in Professional and Administrative positions will grow from about 34 percent in 1990 to 42 percent by the year 2017 . The percentage of women in the senior executive service will grow from 11 percent to about 30 percent.

One reason for the slow movement of women into higher levels is that as the management pyramid narrows, promotion rates for both men and women drop. The MSPB found that on average, about 1 in 8 GS 12 employees is promoted each year, and 1 in 100 GS 15 employees. Gender differences in promotion rates also exacerbate this situation for women. The MSPB found that men are promoted at a rate nearly 33 percent greater than women at the GS 9 level, and 44 percent greater than women at the GS 11 level. These two levels are the gateway into management. When experience and education are controlled, promotion rates for men still exceed those for women. Thus, while promotion rates into the higher levels are low for all, women are at a greater disadvantage than men.

Lower advancement rates for women and minorities have a substantial economic impact on these subgroups. For example, research shows that women still earn significantly less than men. In 1987, the ratio of female to male earnings was found to be .71 (Blau \& Beller, 1988). A recent study conducted with 20 Fortune 500 companies found that women executives had substantially lower salary progression rates than their male counterparts, even when geographic mobility, education level, family power, and standard industry pay were controlled (Stroh, Brett, \& Reilly, 1992).

${ }^{2}$ The 1992 study focused on barriers to advancement for women. Merit Systems Protection Board is currently conducting a similar investigation into barriers to advancement for minority employees in the Federal civil service. 
In sum, despite three decades of legislation intended to correct underrepresentation, and despite evidence that progress, albeit slow, is being made to improve workforce diversity. evidence abounds that real barriers to the advancement of women and minorities continue to exist. In the remainder of this report, we examine reasons that the glass ceiling persists, and recommend ways both to detect its existence and to combat it.

\section{Objectives and Limitations of the Study}

The objectives of this study are threefold. First, the literature survey is intended to identify the most productive approaches to follow in an empirical study of the glass ceiling in the Department of the Army. Second, the report is also intended to provide a research-based context within which to interpret findings of Army's study. Finally, this report highlights promising methods for overcoming or limiting barriers to advancement for women and minorities. Given these objectives, we focused our literature search on empirical studies and sound theoretical articles that investigate explanatory variables and thereby suggest fruitful avenues of research.

As has typically been the case in investigations of the glass ceiling, our treatment of the topic focuses on barriers to advancement within the ranks of management. While obstacles to employment and advancement in non-management jobs clearly affect the composition of the pool of supervisory candidates, the scope of this study did not permit consideration of non-management employment and advancement barriers.

Glass ceiling literature was accumulating long before the phenomenon was given a name. Studies of variables that contribute to or explain slow advancement rates for women and minorities have been conducted in the fields of economics, labor law, psychology, history, sociology, and political science, to name but a few. Much of the literature on the topic of the glass ceiling centers on the problems of women, perhaps because the phenomenon was first described and labelled in a study of executive women (Morrison, White, \& Velsor, 1987). Much of the literature that includes minorities focuses on blacks. This literature review does not represent a comprehensive survey of all that exists on the topic. Rather, because of resource and time limitations, the authors attempted to cover the main findings of relevance to the objectives of the study.

Our report includes an occasional article that examines the situation of Hispanics, and even fewer articles that look at Asian Americans and Native Americans/Alaskan Natives. While we recognize that some of the problems faced by each subgroup are unique, the scope of this study did not permit us to examine unique situations in any detail. Our report therefore mixes literature on gender-specific issues with literature on racial/ethnic issues.

We originally intended to examine barriers to advancement faced by the disabled. Unfortunately, the paucity of literature on this group rendered this objective impossible to meet. It is likely that some of the forces faced by women and minorities are also faced by the disabled, such as the phenomenon of tokenism described in Section III; however, we did not attempt to make such generalizations. As a result, the report focuses on women and minorities. 
Finally, since this project began, the status of gays and lesbians in the military has received a great deal of attention. The attention given to sexual orientation most likely will influence the treatment of gays and lesbians in the civilian work force. However, these issues are outside the scope of this study and are not examined here.

\section{Organization of the Report}

The next three sections of the report are organized around potential causes of glass ceiling: Systemic barriers; stereotypes and biases; and individual factors and group differences. The categorization of causes was taken from a recent literature review by Morrison and Von Glinow (1990). Section II reviews the literature on structural or systemic barriers to advancement. This section presents evidence that widespread policies and practices perpetuate discriminatory treatment of women and minorities.

Section III reviews research that attributes differential treatment of subgroups to stereotypes and biases. In this section, perceptions of individuals, rather than characteristics of the organizational system and the way it operates, are the focus.

Section IV reviews literature that examines whether differences among subgroups underlie slower advancement rates for women and minorities as compared to men. This research typically investigates the extent to which deficiencies are largely responsible for the underrepresentation of women and minorities in the management ranks. The three areas are treated separately for convenience, not because they are unrelated. The variables, findings, and theories treated in each of these sections interact repeatedly.

Finally, Section V, "Conclusions and Recommendations," summarizes the findings reported. This section also presents two sets of recommendations: one suggests promising avenues for research for organizational investigations of the glass ceiling; the other lists actions that organizations might take to reduce barriers to advancement. 


\section{SYSTEMIC BARRIERS}

\section{Introduction}

The limited advancement rates of women and minorities can be attributed, in part, to structural or systemic barriers (Morrison \& Von Glinow, 1990, p. 201). Systemic barriers include widespread policies and practices of the organization or larger social system that often exclude certain classes of individuals from opportunities to share in organizational power, positions of authority, and decision making. Kanter (1979) states that it is the position, not the person, that usually determines whether a manager has productive power. Kanter (1977) defines power as "the ability to do, in the classic physical usage of power as energy, and thus it means having access to whatever is needed for the doing. The powerful are the ones who have access to tools for action" (p. 166). Power is said to be a function of having open channels to supplies, support, and information. Thus, productive power has to do with connections with other parts of the system. Connections, Kanter states, are derived from two sources: (1) job activities (discretion, recognition, and relevance); and (2) political alliances (contact with sponsors, peer networks, and subordinates).

We initially address Kanter's first source of power with a discussion of traditional differences that exist in the position power of jobs typically occupied by men and women. The next section presents research that suggests behavioral and attitudinal implications of power differences in organizations. The remainder of this section addresses Kanter's second source of power: political connections. A discussion of access to information, feedback, and key contacts through membership in networks is followed by an overview of the literature on mentoring: its importance to career advancement and issues with respect to women and minorities.

\section{Power, Authority, and Responsibility}

Dipboye's (1987) review of the literature uncovered numerous power differences between males and females in organizations. For example, Dipboye cited research that found that the number of promotions obtained and the corresponding hierarchical level achieved by managers in an organization is positively related for men, while these achievements are unrelated for women. After controlling the variance due to length of tenure, age, and years of education, female employees were in fact found to obtain more promotions than males. However, the positions into which females moved were lower in the organizational hierarchy than those occupied by their male counterparts. Dipboye (1987) also cited a study of working people that found that control over hiring, firing, and salary was much more likely to accompany a higher status job for men than it was for women. Such literature suggests that even women who have risen to top levels of management still may not have the authority and responsibility usually associated with such positions.

Jacobs (1992) investigated whether the increase in the representation of women among managers between 1970 and 1988 was real or merely a case of women being given managerial titles without the commensurate pay or supervisory responsibility. Jacobs analyzed authority and earnings differentials between male and female managers with data from three 
sources: (a) 1970 Census data on 8,158 managers, of whom 1,463 were female; (b) 1988 Current Population Survey data which included 7,039 managers, of whom 3.084 were women: and (c) data from the 1972-1989 General Social Survey. The results demonstrated that while the gap in earnings among male and female managers did in fact decrease during 1970-1988, the gap in authority continued. For example, female managers were more likely to report having a boss, even though no difference existed between women and men in the distance from the top of the organization. In addition, although the earnings of black women were found to be closely matched to those found for white women, black managers were found to earn less overall than white managers.

Sigelman, Milward, and Shepard (1982) looked at the effects that gender and job responsibility ${ }^{3}$ have on the salaries of men and women in executive, administrative, and managerial positions at a large university. Consistent with prior research, they found significant salary differences between males and females (with a gap of approximately $\$ 5,343$ per annum). The fact that men held positions of higher responsibility than females accounted for over 60 percent of the male-female salary differential. Interestingly, a significant relationship was found between gender and authority type; significantly fewer females were found in line positions than males. The greater part of the explanation of the salary differential therefore had to do with the positional disadvantage of women, with men holding the great majority of positions with high levels of responsibility.

Kanter's (1977) structural perspective views the distribution of opportunity and power and the social composition of groups within organizations as critical variables for understanding women's limited managerial success. Certain jobs/positions are considered to be on career paths that are more likely to lead to career advancement than others. "Staff" positions, for example, may involve important functions, but they are rarely viewed as more than peripheral to the goals of the firm since they do not make the business grow or produce revenues. These jobs are "actually" and "symbolically" less visible; actually, because such jobs do not involve contact with clients and the market, and symbolically because they are not defined as crucial (Epstein, 1975, pp. 9-10). Kanter (1979) states that staff professional positions are typically powerless, and, because they are often viewed as adjuncts to primary tasks, their effectiveness and thereby their contribution to the organization is often difficult to measure. Kanter further notes that experience in staff positions alone tends to limit the number of jobs into which an individual can move. Thus, not surprisingly, staff positions do not tend to lead to top management positions. "Line" jobs, on the other hand, are thought to be in the mainstream of the business and result in top management posts. Individuals without line experience, therefore, will have difficulty moving up in the organization (Kanter, 1979).

Numerous studies have reported that minorities and women are more likely to populate dead-end or staff jobs while white males are more likely to populate high visibility or line jobs. For example, the Department of Labor (1991) study of employment practices in the

${ }^{3}$ Responsibility was operationalized as a weighted combination of 13 factors of which the most heavily weighted included employee's job experience, extent of supervisory authority, complexity of the position, range of policy discretion associated with the job, and the assets controlled by the position. 
private sector found that women are more often found in staff positions (e.g., human resources or research) than are men. Almost all of the companies examined had few, if any, minorities and women at the highest levels of management--when they were present, they were almost always in staff functions. Few minorities and women were found in such line professions as defense systems, electronics, commercial lending, and sales.

Generally, only those Federal employees who are in occupations classified as Professional or Administrative become managers or executives (Merit Systems Protection Board, 1992). While women doubled their representation in Professional and Administrative jobs between 1974 and 1990, nearly two-thirds of these positions are still held by men. Women occupy a minority of the feeder positions (i.e., positions from which managers or executives are most likely to be chosen), and when found in these occupations, they are more likely to be in lower graded jobs than men.

A large-scale survey conducted in the private sector found a similar result. Fernandez (1981) surveyed a random sample of 4,191 managers in 10 corporations. His sample included Native Americans, Asians, Hispanics, African Americans, and whites. Thirty-four percent of the respondents said they believe that women are positioned in dead-end jobs. Women in each race group were more likely to believe this than were men; the responses ranged from 53 percent agreement for Hispanic women, to 44 percent for black women, to 25 percent for white and Asian men. Fernandez explained the perception of women as not having the same power as men, in part, by results indicating that 27 percent of managers believe that men are generally unable to work comfortably with women and that men bypass women and go to their superiors; black women ( 50 percent) were most likely and white men ( 17 percent) were least likely to believe this to be the case.

Fernandez (1981) also found that 21 percent of managers surveyed believe that minorities are placed in dead-end jobs. It should be noted that there was a large disparity in perception between source groups; 51 percent of black managers and 6 percent of white men agreed with the statement. While it is unclear what factors account for the disparity, (e.g., different groups may have had different expectations), such findings seem to suggest that female and minority managers may not be assigned the sar: responsibilities as their white male colleagues.

\section{Behavioral and Attitudinal Implications of Power Differences}

Stunted Development. Blocked Progress. Morrison et al. (1987) suggest that having the opportunity to tackle challenging assignments and successfully complete them are vital to an executive's career development. Morrison and Von Glinow (1990) note that these assignments seem to be less available to women and minority managers, thereby blocking their advancement. The U.S. Department of Labor (1991) also found that developmental practices and credential-building experiences (e.g., career enhancing assignments such as appointments to corporate committees, task forces, and special projects) often were not available to women and minorities to the extent that they were available to white males.

Dipboye (1987) cited laboratory research on male managers and college students that showed that male managers are less likely to assign a female subordinate to a challenging task 
than they are to assign a male subordinate. Morrison (1992) reporied a similar finding from extensive interviews conducted with 16 public and private sector organizations. White male executives were found often to be reluctant to give highly visible and challenging assignments to either female or minority managers.

A survey of 117 male and 117 female managers with MBAs who had been in the working world for a few years revealed that women were more likely to report that the job assignments they had been given (e.g., highly detailed work) had kept many of them from developing social networks. Their male colleagues, on the other hand, reported that they were out making contacts, forming coalitions, and increasing their visibility within the organization (Rosen et al., 1981).

Powerless Behavior. The amount of power individuals are given in their jobs also has ramifications for their resulting behavior. Two theories exist as to the effects of working in jobs with power limitations. Structuralist theory states that the lack of information and support that accompanies low-power jobs will cause all such job holders, regardless of gender, to behave in a powerless manner. Socialization theory suggests that women and men may differ in the influence strategies they use as a result of their learned experiences and that such differences will appear regardless of structural inequities. Mainiero (1986) tested the two theories in an investigation of the effect that gender and job dependency have on various empowerment strategies used in a dependency situation, defined as a situation in which study participants had to rely on someone else for task or career reasons.

Mainiero used the critical-incident technique to obtain examples from men and women employed in an organization which described frustrating workplace situations in which they were powerless and dependent on others. The incidents also described the action they took in response to the situation.

In contrast to some research findings Mainiero (1986) found that men and women were equally associated with powerful (and powerless) jobs. In support of the structuralist theory, Mainiero found that individuals, especially women, in high-dependency jobs were more likely to acquiesce than individuals in low-dependency jobs. However, relative job dependency had a greater effect than gender on the use of the acquiescence strategy.

Individuals in high-dependency jobs felt their jobs were structured in such a constraining manner that they had no alternative but to respond with acquiescence. Thus, their actions were a result of their own powerlessness. The suggestion was made that women may be contributing to their own powerlessness by the disproportionate use of this strategy. Mainiero concluded that poorly designed jobs that force individuals to be excessively dependent on others create frustration and a sense of helplessness.

Mainiero also found that individuals in high-power jobs were more likely to search for alternatives than individuals in high dependency or low-power jobs. Mainiero's findings support Kanter's (1977) hypothesis that powerless jobs may cause individuals to behave in powerless ways. While both the structuralist and the socialization theories were found to aid in an understanding of the gender differences in empowerment-strategy usage, the structuralist hypothesis appears to have greater support. 
Different Subgroups, Different Realities. Men, women, and minorities do not share a common culture of organizational life. Rather, each group identifies, defines, and organizes its experience in its own way. Women, who hold lower level positions at lower salaries than men, typically view the organization from the bottom. Minority employees tend to view the organization in isolation since there are few minorities with whom to establish significant working relationships. Each group seems most comfortable communicating with their own group. Women and minorities identify interpersonal barriers or systemic bias as obstacles to their success whereas white men see formal structures and policies as eliminating any obstacles (Alderfer, Alderfer, Tucker, \& Tucker, 1980; Fine, Johnson, \& Ryan, 1990).

Fine, Johnson, and Ryan (1990) conducted a survey that was developed based on issues Federal government employees raised, such as place in the hierarchy, communication networks, criteria for promotion, and sexual harassment. The survey was completed by 242 employees in a Federal agency. Fifty percent of the respondents were female and 12 percent were minorities. The respondents were distributed evenly among Professional, Administrative, Technical, and Clerical positions.

The responses revealed a pattern in which minorities and women identify attitudinal and cultural barriers to promotion whereas white men state that structural changes have eliminated those barriers. White males appear least aware of the concerns of women and minorities. They tend to believe that racism and sexism are no longer a problem at the workplace. For example, in response to a question about whether women face unique obstacles to promotion, 57 percent of women compared to 27 percent of men answered yes. Three key obstacles to women's promotions identified included: Women must work against a male culture; an "old boys" network isolates women; and women are negatively stereotyped based on gender. Males tend to believe that women receive government and agency assistance and are sometimes given preferential treatment. Minorities (79 percent) were much more likely to perceive obstacles for their own promotions than were whites (42 percent).

Alderfer et al. (1980) and Fernandez (1981) reported a similar pattern of responses. In both surveys, women and minorities perceived their opportunities to be much more limited than did white males. White males, on the other hand, were much more likely to perceive that a system in which employee treatment was based on merit had been replaced with one in which women and minorities were favored because of affirmative action. Alderfer et al. factor analyzed the questionnaire responses of whites and blacks separately, and described the different factor structures in the following way:

"White managers tended to group questionnaire items according to properties of individuals (e.g., blacks were pushy, brought low standards, etc.) while black managers tended to correlate characteristics of the organization (i.e. XYZ is racist, biased against blacks, etc.)...On the subject of advancement, blacks tended to group together items relating to how the $\mathrm{XYZ}$ promotional system was structurally biased against blacks, while whites correlated items that indicated how underserving blacks were receiving accelerated promotions instead of qualified whites" (p. 148). 
Alderfer suggests that blacks and whites hold different cognitive theories to explain the organizational world within which they live. Fine et al. (1990) suggest that organizations use this perspective, in which gender and race are viewed as cultures, to serve as a constructive framework for understanding cultural diversity and successfully managing a diverse workforce.

\section{Networking}

In addition to experiencing limited access to positions and experiences that will favor their careers, women and minorities may also find that they have limited exposure to the informal frameworks that exist in organizations. Those individuals who make up such networks are typically those who have had the positions of power and responsibility as previously discussed.

Networking, as defined by the Merit Systems Protection Board 1992 report, "is a broad concept which can include anything from calling upon a colleague for work-related information to developing long-term relationships with present or former work associates. Contacts with a network can be on the job or in the context of social activities" (p. 24). Participation in informal networks is viewed as an important element for the success of a career. Epstein (1975) notes:

"The more we study people who are ostensibly "self-made," the more we see that what really made them is not only their idiosyncratic set of talents but also the framework in which they lived, the opportunities available to them, and the role of persons important in their lives in the formation of a self-image that facilitated career attainments" (p. 16).

Relating to other managers is an important part of most managers' jobs (Dipboye, 1987). Interactions with other managers or superiors can provide feedback that facilitates career development (Rosen, Templeton, \& Kichline, 1981), and information and contacts that reveal career-enhancing opportunities (Fernandez, 1981). Since general management is the point at which managers are either admitted into the "club," or excluded if they lack the proper background, image, sex, and so forth (Morrison et al., 1987), exclusion from informal networks is a potential barrier to the advancement of minorities and women.

Informal Interactions. There is some evidence that female as well as minority managers may feel excluded from informal relationships with their white male colleagues. For example, Rosen et al. (1981) found that more than 60 percent of female managers felt that they had been excluded from the "informal organization." In addition, women reported significantly fewer interactions with their supervisors than men. Interestingly, 41 percent of women responding to a series of open-ended questions stated that, compared to their male colleagues, they lacked skills in organizational politics.

Sixty-one percent of all the managers in the Fernandez (1981) survey agreed that men often exclude female managers from informal networks. In addition, 35 percent of white female managers and 39 percent of white male managers agreed that female managers have difficulty initiating informal work-related activities such as lunch dates and drinks after work 
because men misinterpret their behavior as sexual advances. Epstein (1975) notes that "when women cannot mingle easily with men as colleagues in the informal settings where business gets done, they cannot become fully prepared to exercise influence" (p. 14).

The Fernandez (1981) survey results also show a strong perception that minorities are excluded from informal networks. Between 21 and 31 percent of male and female NativeAmerican, Asian, Hispanic, and white managers believe that minority managers are excluded from informal workgroups by white managers, whereas 71 percent of black men and 59 percent of black women believe this is true. Also, Fernandez found that among whites and blacks of both sexes, upper-level managers were more likely than those at lower levels to believe minority managers were excluded from informal work networks by whites. Jones (1986) reports that despite how talented or well trained they are, "black managers feel they are treated as outsiders, and because of the distance that race produces, they do not receive the benefit of these networks and relationships" (p. 89). In a survey of the banking industry (Irons \& Moore, 1985), 75 percent of the respondents ranked not knowing what was going on in the organization or not being in the network as the most serious problem faced by blacks. Racism and the inability to get a mentor were ranked as the second and third most significant problems, respectively. The Merit Systems Protection Board (1992) report, on the other hand, did not support the notion that women (or men) are isolated in gender-based groups which serve as the primary source for work-related information and advice.

Recruiting Differences. Another way that networks can aid individuals in their career advancement is by assisting them in making a job change. To the extent that exclusion from informal networks reduces the information on job opportunities, one would expect to find that the recruiting process acts as a barrier to advancement.

The literature speaks of formal recruiting sources (e.g., public and private employment agencies, radio, television, newspapers, professional journals) and informal recruiting sources (e.g., employee referrals, referrals by friends or relatives). The literature tends to show that the informal recruiting sources produce superior new hires to those recruited through formal sources (Kirnan, Farley, \& Geisinger, 1989).

Kiman et al. investigated the frequency with which various recruiting sources were used by applicants for the job of life insurance agent in a large insurance company. Both female and black applicants reported using newspaper advertising as a recruiting source to a much greater extent than their male and non-minority or Hispanic counterparts. Group differences were even more apparent when the informal sources such as agent referral, sales manager referral, district manager referral, clerical referral, and mutual acquaintance, were compared with formal sources such as newspaper advertisement, employment agency, and school placement. Females and blacks used a proportionately greater number of formal recruiting sources than did their male and non-minority counterparts. These results suggest that women and minorities are not tied into informal networks and may, therefore, be less likely to hear about some jobs through this recruiting source. The Kiman et al. (1989) study also found that informal recruiting sources produced significantly higher selection ratios than did formal sources for all groups. The informal recruiting sources yielded higher quality applicants and more successful hires for all groups. 
The Department of Labor (1991) report confirmed the notion that most larger companies fill management vacancies from within using various methods. Corporate executives often learn of potential candidates through their informal networks, casually interview them, and ultimately make offers. Lacking such contacts handicaps minority and female career advancement. Companies also recruit through employee referrals. Although companies vary on how elaborate such referral systems are, some companies pay their employees for referring candidates who are later selected. Although the Department of Labor pilot reviews were unable to determine if such referral systems are discriminatory, neither minorities nor women were hired into middle- and upper-levels through this method, nor did they provide referrals.

Reliance on internal recruitment appears to promote homogeneity of work teams (Jackson, Brett, Sessa, Cooper, Julin, \& Peyronnin, 1991). The authors found significant correlations between the percentage of new executive team members recruited within the firm and age, college curriculum, experience outside the industry, and military experience. Insufficient numbers of minorities and females at the executive levels on which this study focussed precluded exanination of race and gender effects.

Executive search and referral firms are a cummonly used external recruiting source. The majority of the companies found to use this method in the Department of Labor (1991) study, however, did not make the executive recruitment firms aware of their equal employment and affirmative action obligations under the law. In addition, when such firms suggested candidates that did not include minorities or women, many of the companies neglected to demonstrate good faith efforts to broaden the pool of candidates from which they had to choose.

The potential diversity of applicant pools is further reduced given the limited involvement of EEO directors. While EEO directors may be involved in the staffing of lower level positions, they often are not included in the recruitment process above a certain level (e.g., mid- and upper-level positions) (Department of Labor, 1991). As EEO directors prove to be a valuable resource with the contacts and means by which to advertise more broadly, their exclusion from the selection process can have a direct effect on minority representation in organizations, particularly in those positions of power previously discussed.

\section{Mentoring}

Mentoring has been defined as "a relationship in which a person of greater rank or expertise teaches, counsels, guides, and develops a novice in an organization or profession" (Alleman, Newman, Huggins \& Carr, 1986, p. 1). In many occupations, mentoring relationships facilitate the career development and advancement of employees (e.g., masterapprentice, physician-intern, and teacher-student). The literature suggests that a relationship with a mentor adds measurably to the success of people at work. Managers who have been mentored report more promotions, higher incomes, bonuses, total compensation, and pay satisfaction than managers without mentors (Alleman et al., 1986; Dreher \& Ash, 1990; Hunt \& Michael, 1983; Roche, 1979). Successful managers tend to have someone in the organization who acts as their mentor or sponsor (Hunt \& Michael, 1983; Roche, 1979). Exclusion from mentorships, therefore, is a potential barrier to career advancement. 
In Fernandez's (1981) survey, managers ranked having a sponsor as one of the top three factors involved in obtaining desired positions. According to Fernandez little variation among the race/sex groups was found in the belief that having a sponsor/mentor is an advantage; between 67 percent and 76 percent believe it to be an advantage. In Fitt and Newton's (1981) survey of female managers in 27 different Northeast and Midwest companies, 24 of the 30 women in their sample reported having mentors. These women. on average, were both better paid and younger than the six women who had never had a mentor. Furthermore, Roche (1979) noted that respondents who had a mentor, in addition to being more successful, were happier with their career progress.

There is an important difference between formal and informal mentorships. Informal mentorships are not managed, structured, or formally recognized by the organization. but spontaneously occur; formal mentorship programs on the other hand are both managed and sanctioned by the organization (Chao, Walz, \& Gardner, 1992). Chao et al. conducted a field study that compared 212 protégés involved in informally developed mentor relationships, 53 protégés in formally developed mentor relationships, and 284 persons who were not involved in mentor relationships at all. The groups were compared on three outcome measures: salary, job satisfaction, and organizational socialization. The results showed that protégés involved in informal mentoring relationships reported higher salaries and more career-related support from their mentors than did protégés involved in formal mentoring relationships. Only the informally mentored protégés reported significantly more favorable outcomes (salary, job satisfaction, and organizational socialization) than those who were not involved in mentor relationships.

The reasons for these results are unclear. It may be that within informal mentorships, mentors select the highest performers to mentor. On the other hand, in formal mentorships, the mentor has less control over the ability level of the protégé. As a result, higher average ability levels in groups that have been informally mentored may account for the greater success among this group. Alternatively, a relationship that forms with a higher level manager spontaneously, as in an informal mentorship, may be more beneficial than one based on an organizational pairing process.

The Merit Systems Protection Board (1992) reported that more women than men perceive that having a senior person/mentor is helpful to career advancement. There is some evidence, however, that women and minorities have more difficulty finding a mentor than white males. For example, in Fernandez' (1981) study, 40 percent of the managers believed that many minorities, and 44 percent believed that many women, have a much harder time than white men in finding a mentor. Similarly, Rosen et al. (1981) found that more male managers (62 percent) than female managers ( 50 percent) felt that there was someone in the organization who had taken a special interest in their careers. Dreher \& Ash (1990) surveyed 440 business school graduates about their mentoring experiences. They found no gender differences in the frequency of mentoring relationships, nor in mentoring-outcome relationships. In short, research results are inconclusive as to whether women and minorities actually find fewer mentors than do white men (Morrison \& Von Glinow, 1990; Thomas \& Alderfer, 1989). 
Since there tends to be a shortage of high-level female role models or mentors. especially in traditionally male-dominated careers, it is often the case that a woman's mentor will be a man (Hunt \& Michael, 1983; Roche, 1979; Sheehy, 1976). This fact poses a potential problem for women since gender can influence the nature and outcomes of mentorprotégé relationships (Hunt \& Michael, 1983). Because little information exists on femalementor female-protégé or female-mentor male-protégé relationships (Hunt \& Michael. 1983), the research addressed here mainly applies to male-mentor female-protégé relations. In mixed gender mentoring relationships, the protégé and mentor may be presented with sex-related problems (Fitt \& Newton, 1981). For example, there is the risk that a close association could evolve into a romance or sexual entanglement or that it simply could be perceived as such. Still, while full-blown affairs resulting from a sponsor relationship may be uncommon, the experience of sexual tension is not (Fitt \& Newton, 1981). Sheehy (1976) suggests that if the mentor-protégé relationship is to be successfully kept on a career basis, an increased level of maturity is called upon on the part of the mentor to cope with the possibility of sexual relations.

Another problem associated with male-mentor female-protégé relationships is that collusion in stereotypical behaviors can occur. Sheehy (1976) and Kanter (1977) point out that stereotypical roles influence the relationship and may interfere with the establishment of a relationship that is supportive of psychosocial development. For example, women may be encouraged to maintain feelings of incompetence and dependency when they are trying to become independent contributors.

The reports of benefits of mentoring relationships are usually based on studies using white male subjects. However, mentor relationships may have greater impact on the careers of blacks (Alleman et al., 1986). Alleman et al. compared the mentoring benefits and experiences of black and white men without mentors to black and white men with black or white mentors. Mentoring relationships were similar regardless of race, but mentored blacks reported significantly higher levels of perceived career benefit and satisfaction than did mentored whites. Although there was no significant difference overall between black and white non-mentored employees, white employees scored significantly higher than black employees on five of the twelve subscales on the instrument used to measure mentor behaviors. The authors concluded that non-mentored black employees may receive less helpful cues for supervisory behavior than non-mentored white employees.

Thomas and Alderfer (1989) noted that blacks differed significantly from white males and white females by having more extradepartmental and organizational relationships as well as more relationships with other blacks and white females. The authors state that the most significant factor accounting for this difference was the location of black employees: black mentors and sponsors were most frequently outside of the department. Furthermore, samerace relationships provided significantly more psychosocial support than cross-race relationships although cross-race and same-race relationships did not differ significantly in the amount of instrumental career support they provided. 


\section{Summary}

Men tend to hold more powerful positions with higher levels of responsibility and authority than women. Minorities and women have traditionally been more likely than men to occupy staff jobs or dead-end positions, and this is still the case. Thus, women and minorities tend to be on a career path that is less likely to lead to career advancement. Compounding the historical trend is the apparent reluctance of white male managers to give women and minorities highly visible, challenging assignments, thus denying them the types of experiences that promote the development of managerial and executive talent.

Powerless jobs promote powerless behavior. While women may be more likely to acquiesce than men, high-dependency jobs foster use of that strategy regardless of gender. Confinement to lower level, staff, or dead-end jobs may promote management styles and behavior that are viewed as ineffective, further reducing possibilities for advancement.

There is some evidence that women and minorities are excluded from informal networks that provide the information, feedback, and contacts necessary for career advancement. Related to the exclusion from informal organizational networks is exclusion from informal recruiting networks. Reliance on informal recruiting sources reduces the likelihood that minorities and women will hear about jobs, particularly higher level jobs.

Successful managers tend to have a mentor. Additionally, the benefits of an informal mentorship are greater than those of a formal mentorship. Minorities and women who are locked out of networks might have difficulty finding mentors. Research results are inconclusive on this point. There is some evidence that women and minorities have more difficulty finding a mentor than do white males, although recent research suggests that this is not the case for women. Mixed-gender relationships pose potential problems in establishing a relationship that is supportive of a female manager's development.

Women and minorities identify attitudinal and cultural barriers to promotion, whereas white men are more likely to feel that structural changes have eliminated those barriers. White males seem to see fewer obstacles to power sharing than do women and minorities; some white males perceive affirmative action guidelines to give minorities and women an unfair advantage in the work place. To the extent that those in a position of power fail to initiate the changes required to remove barriers to advancement, the glass ceiling will remain. At the same time, perceptions of favoritism and inequity may slow down or undermine efforts to increase diversity in the highest levels of management. 


\section{STEREOTYPES AND BIASES}

Stereotypes and associated bias underlie the belief that minorities and women are not suited for managerial positions. Such beliefs, thought to be one of the major causes of employment inequities (Morrison \& Von Glinow, 1990), are the subject of this section. Most of the research discussed here addresses women's issues, given the unfortunate lack of focus on the minority populations in the literature. Still, according to the data presented by Leinsten (1988) and others, black individuals fair even more poorly than females in traditional organizations. This is particularly the case when one considers the plight of "doubly disadvantaged" minority females. Malveaux and Wallace (1987) comment on the additional deficit in research on women of other minorities, noting that when non-black minorities are studied they are typically placed into an all-encompassing minority group. This lack of research is reflected in the discussion of the literature that follows.

Stereotypes are the products of a normal psychological process of categorization, whereby intracategory similarities and intercategory differences are accentuated (Tajfel, 1982). Tajfel proposed that stereotype formation serves two functions: a cognitive function and a value function. The cognitive function simplifies the complex network of social relationships confronting individuals in their environment. That is, stereotyping is the process of "chunking" information to facilitate social decision making. The value function leads to a growing emphasis on ingroup similarity and outgroup differences, which "serves to protect, maintain, or enhance the value systems applying to distinctions between social groups" (p. 21). Such maximization of differences and associated favoring of ingroup members preserves that part of the individual's self-concept determined by his or her social identity. A corollary of ingroup favoritism is discrimination against outgroup members. Thus, discrimination is a correlate of the natural process of stereotype formation.

How stereotypes can influence the expectations one has for outgroup members, and one's perceptions and evaluations of their behavior, are the subject of this section. We begin with a review of gender-specific performance expectations. Following this, gender and race effects in the evaluation of performance are discussed. Next, an overview of how stereotypical beliefs can be perpetuated is presented. The section ends with a discussion of the devaluation of stereotypically minority jobs.

\section{Gender-Specific Performance Expectations}

Sex is an obvious basis for social categorization and sex stereotypes are the result. Terborg (1977) identified two components of sex stereotypes. The first involves attributes or behaviors deemed to be characteristic of each sex. For example, men are seen to be assertive and strong, while females are perceived to be caring and emotional (Colwill, 1987). The second component defines appropriate behavior for men and women. The former, descriptive component, is a belief about what men and women are like; the second, prescriptive component, dictates what men or women should be like. Just as a man should not be passive or sensitive, it is deemed inappropriate for a female to be competitive or independent.

A large body of literature indicates that descriptive stereotypes influence attitudes about the proper place and effectiveness of men and women in the workplace, and that such 
commonly held attitudes may block career development for women. For example, Dubno's (1985) longitudinal study of attitudes towards women executives demonstrated that male MBA students harbor negative attitudes towards women managers; female MBA students viewed women executives more positively. Dubno concluded that such polarized attitudes on the parts of MBA students who represent a large proportion of aspiring managers in the business world will ensure the continued prevalence of discrimination against female managers, blocking their career development. Successful promotion to the upper echelons of the organization requires an independent, aggressive, and competitive individual. If women are not thought to possess such attributes, they would not be considered for such a position.

Freedman and Phillips (1988) note that a great many studies have found that male applicants are rated higher for traditionally male jobs while female applicants are rated higher for traditionally female jobs. Should a female therefore apply for a traditionally male job, it has been shown that she will act:ally be discouraged from further pursuit of this path (Dipboye, 1987). The most thoroughly researched area within this topic is that of the traditionally white male position of manager. Leventhal and Herbert (1990) note that females who wish to move up the corporate ladder have been advised to adopt more masculine characteristics in order to be accepted by both their superiors and their subordinates. It is widely believed that women would do better in their work roles if they were to hold attitudes and behave more like men (Freedman \& Phillips, 1988). However, "behaving more like men" is incompatible with the prescriptive stereotype that dictates how women should behave, and leads to gender-incongruent behavior.

In an employment setting, individuals fill an organizational role defined by what is expected and appropriate behavior required to perform the job. In addition, people develop expectations about others' behavior based on what is considered to be appropriate for their gender. When gender-based expectations are carried over into the workplace, the carry-over is termed "sex-role spillover" (Gutek \& Cohen, 1987). Gutek and Cohen point out that the work roles which have been dominated by white males in the past have taken on the characteristics deemed typical of this majority. Terborg (1977), in fact, holds that a "male managerial model" exists that all but ensures that women cannot be successful in management as it perpetuates the stereotype that women should not be successful in management. Thus, sex-role spillover in management jobs is greater for female than male incumbents because the disparity between expectations of the gender role and job role is less for males.

Sex stereotyping and sex-role spillover may be accentuated when women are numerically rare. Research that addresses the sex-ratios of groups within organizations is relevant here. Kanter's (1977) research defines women as "tokens" when they are in management groups where 85 percent or more of the members are men. In such groups these women tokens stand out as their sex is different from the majority of the group. As such, they visibly represent women as a category. Such visibility subjects tokens to pressures other group members do not have. In addition, members of the dominant group may exaggerate differences according to their stereotyped beliefs regarding women. Women are judged to be less qualified and have less potential when they are few in number. As a result, when token women are recognized for their work, the recognition is more likely to be attributed to their gender than to their own accomplishments. Such negative factors hinder tokens by creating a hostile environment towards their productivity, perceived success, or advancement. 
Both women and men state that women are held to a higher standard of performance and must work harder than men to succeed (Merit Systems Protection Board, 1992; Valerio, 1990). Not only do a large number of females think that they are presumed to be incompetent until they prove otherwise, but they also believe that the errors they make receive far more attention than do those made by males.

Leinsten (1988) notes that there is also a pervasive belief that blacks cannot perform as well as whites and that when they do meet a higher level of performance, it is surprising. Blacks also feel that they must work harder than whites to prove themselves, and that they are not allowed the same luxuries as whites in making mistakes. Rather, black individuals feel as if they are responsible for holding up the reputation of their race (Alderfer et al., 1980). The general conviction is that if one black individual does not meet performance standards, the stereotype of poor black performers is reinforced against all black individuals. This situation is magnified as the ratio of females/minorities to males shrinks.

\section{Performance Evaluations and Stereotyping}

Thomas and Alderfer (1989) state that the modern organization is one that is founded on distributive justice principles or what they term to be "meritocracy," where individuals are rewarded based upon their performance. In contrast, Dipboye (1985) hypothesized that raters process information about individuals differently given the stereotypes they hold for similar individuals as a whole--regardless of performance. One way that stereotypes might operate to block the advancement of women and minorities is through the differential evaluation of performance.

Kraiger and Ford (1985) investigated the effects of race on performance ratings through the use of meta-analysis. Results indicated that whites rated white ratees higher than black ratees. Black raters, on the other hand, gave significantly higher ratings to black ratees than they gave to white ratees. The only substantial moderating effects found in the study involved the setting of the ratings and the saliency of blacks in the workgroup. The magnitude of the rating differences was greater in field studies than in laboratory studies, while race effects were found to decline as the percentage of blacks in the workgroup increased.

Pulakos, White, Oppler, and Borman (1989) looked at both race and sex effects on performance ratings collected from a large sample of enlisted Army personnel. Because multiple raters had evaluated each ratee, Pulakos and her colleagues could separate the effects of actual ratee performance differences from the effects of rating bias in the evaluations. Ratings were collected from peers and supervisors on three composite behavioral dimensions: technical skill and job effort, personal discipline, and military bearing. Although significant results were found, the proportion of variance accounted for in the ratings by the independent variables of race and sex was determined to be extremely small. Pulakos et al. (1989) went on to conduct a meta-analysis regarding the nature and magnitude of race and sex effects on performance ratings. Once again, although some significant race and sex effects were found, very little of the variance in the ratings was correlated with race and sex. Pulakos et al. noted the possibility that the effects of race and sex on associated ratings may have been smaller here than in other research given the focus on the military population. As there is a 
greater percentage of minorities in the military than in the civilian workforce, military raters may be more accustomed to rating minority performers.

Oppler, Campbell, Pulakos, and Borman (1992), again using the Army data, found that supervisor ratings were more performance-related and less influenced by ratee race than were peer ratings. Additionally, they found much higher agreement between black and white supervisors than between black and white peers, regardless of the race of the ratee.

The amount and type of information available to raters might mitigate the influence of stereotypes on ratings. Stereotyping is most likely when evaluative criteria are ambiguous, and when information about the ratee is limited or ambiguous (Heilman \& Martell, 1986; Heilman, Martell, \& Simon, 1988; Fiske, Bersoff, Borgida, Deaux, \& Heilman, 1991). When information is open to multiple interpretations, stereotypes can provide structure and meaning. In the Pulakos et al. study, rating scales were rigorously developed and tied to important job components, raters were extensively trained in their use, and raters evaluated individuals with whom they worked on a daily basis. Thus, it is likely that performance information rather than stereotypical beliefs affected ratings.

Tsui and Gutek (1984) listed a number of factors that worked to minimize bias in the ratings they studied, including the standardized rating procedure, management training in evaluation, affirmative action guidelines, and potential consequences to raters who assign ratings that must be defended. In addition, ratings were collected in a field setting where individuals involved are known to each other, and thus may be less susceptible to the influence of stereotypes. Tsui and Gutek collected ratings from industrial middle managers and their supervisors, subordinates, and peers on performance effectiveness and affective relationships (admiration, respect, and liking). In addition, they collected measures of career success. The authors reported that women managers received larger merit increases and had faster promotion rates than their male counterparts. They also reported higher levels of job satisfaction. No significant rater sex effect was observed among subordinate and peer raters. Too few supervisors were females to permit analyses of sex effects among supervisory ratings. Examination of formal company performance appraisal ratings showed that ratings were similar for the two sexes.

Eagly, Makhijani, and Klonsy (1992) reviewed the experimental literature on the evaluation of women and men who occupy leadership roles. Their meta-analysis included only experiments whos: jesigns held constant the characteristics of leaders other than their sex and varied the sex of the leaders. With such designs, any differences in evaluations of women and men can be ascribed to subjects' biased perceptions.

Eagly et al. found only a slight tendency for female managers to be devalued across the 56 studies they reviewed. Leadership style did, however, affect evaluations of male and female leaders. Women leaders were devalued relative to their male counterparts when they employed a stereotypically masculine leadership style, particularly when this style was autocratic or nonparticipative. Moreover, the devaluation of women was stronger when leaders occupied male-dominated roles and when evaluators were men. 
Sex-role stereotypes were operative in the case Price Waterhouse v. Hopkins (Fiske, Bersoff, Borgida, Deaux, \& Heilman, 1991). Ann Hopkins was the only woman of 88 candidates proposed for partner in 1982; of the 662 Partners at Price Waterhouse, only 7 were women. Hopkins' objective indices of performance were exceptional; she had more billable hours that year than any other candidate, she had brought in $\$ 25$ million in business, and her clients praised her. Despite these accomplishments, Hopkins did not make partner because of "interpersonal skills" problems. Hopkins was described by evaluators as "macho", as overcompensating for being a woman, and as needing a "course at charm school." She was advised by colleagues to "walk more femininely, talk more femininely, dress more femininely, wear make-up, have her hair styled, and wear jewelry" (Hopkins v. Price Waterhouse, 1985, cited in Fiske et al., 1991). In the Civil Rights case that followed Hopkins' complaint, the testimony of Psychologist Susan T. Fiske enumerated the antecedent conditions that promote stereotyping (Fiske et al., 1991), all of which seemed to operate in the Hopkins case, as follows:

- the target individual is one-of-kind or few-of-a-kind in an otherwise homogeneous environment

- the job is nontraditional for members of the target group

- there is a perceived lack of fit between the person's category and occupation

- $\quad$ evaluative criteria are ambiguous, requiring subjective judgments

The field research on performance ratings demonstrates extremely limited race and sex effects in evaluations of performance. Similarly, the experimental literature on gender and the evaluation of leaders reveals slight devaluation of the performance of women relative to that of men, except for the cases in which the roles and behavior of women leaders violate gendercongruent expectations. Various conditions known to mitigate the influence of stereotypes in performance evaluation were present in many of these studies. However, many facilitators of bias were operative in the "real-life situation" faced by Ann Hopkins, and according to the courts, the evidence demonstrated that her treatment was influenced by sex-role stereotypes.

\section{Perpetuation of Stereotypical Beliefs}

Dipboye (1987) notes that individuals are no longer willing to acknowledge that they hold stereotypes. Most individuals truly believe now that if stereotypes are not wrong, they are at least politically incorrect. It would therefore be unwise to acknowledge that one continues to hold biases that he or she has developed over the years. As such, there is the desire to provide a socially acceptable answer to the question of the use of bias rather than a completely truthful one. Dipboye's argument suggests that the attributions underlying stereotypical beliefs merit closer examination.

Rational Bias Theory. Rational bias involves the situation where discrimination is permitted and even valued in the organization (Morrison and Von Glinow, 1990). Individuals who discriminate are hypothesized to do so as they believe they may actually be rewarded for their action. Larwood, Gutek, and Gattiker (1984) state that such behavior does in fact occur. Specifically, Larwood et al. (1984) note that the individual in question makes a decision to discriminate based upon the extemal pressures that exist in the workplace. If it is deemed likely that coworkers will not accept a woman or minority worker, for example, these 
preferences will be taken into account with the rationale that the continued satisfaction and productivity of the group will be preserved.

Larwood, Szwajkowski, and Rose (1988) attempted to test this theory by looking at the type of person management students would bring to a client who is known to have discriminatory beliefs. Students preferred taking males and whites over females and blacks to the client visit. The individuals making such choices apparently felt that they would be able to maintain and even further their careers by deferring to the bias. As a whole, the study also demonstrated that subjects feel a business norm exists that favors discrimination against women and minorities. Such norms rationalize discrimination for the good of the business, and thereby support continuation of discriminatory practices. Adherence to such norms may, in fact, be rewarded with career advancement. Such findings may partially explain why stereotypes and bias prevail while regulations are in place that are designed to prevent their perpetuation.

Affirmative Action. The precept behind affirmative action policies was to benefit those individuals who previously had been underrepresented in the workforce--where ratios had traditionally favored the white male. The idea of such policies therefore was to decrease, if not eliminate, discrimination and prejudice in the work environment. These undesirable practices may unfortunately be amplified by the existence of affirmative action practices. In focus groups conducted by the Merit Systems Protection Board (1992), for example, the women present felt that they were discounted on the job because males felt that women advanced in their careers due to gender rather than qualifications. Similar feelings have been expressed on the part of male and female black executives. Leinsten (1988) notes that many black individuals feel that their white peers think they are moving forward in their careers on the basis of quota fulfillment rather than competency-based merit. Add to that the stigma of being an affirmative action hire and it is highly unlikely that the majority will deem the female or minority to be competent. Apparently, such feelings were accentuated during the Reagan years given the administration's position that affirmative action policies not only did not work but were also unnecessary (Leinsten, 1988).

Heilman, Simon, and Repper (1987) explored the messages conveyed to affirmative action hires as to their sense of competence. Given the aforementioned stereotypes that exist regarding the characteristics one must have to lead, it seems only natural that women should harbor self-doubt as to their capabilities to handle the job for which they have been selected. To determine if such feelings do in fact exist, Heilman et al. (1987) looked at the effects that sex, job assignment method (merit-based or sex-based preferential selection), and task outcome (success or failure) had on subjects' perceptions of their leadership ability, their performance evaluation, their assignment of responsibility, and their desire to persist in a leadership role. In the presence of sex-based preferential selection, a negative effect existed regarding both women's self-perceptions and their evaluation of themselves as leaders. The strength of such feelings was further demonstrated given that contradictory positive information was provided to female subjects regarding the quality of their performance. Thus, even when females had the knowledge that they certainly would have been selected on the basis of merit, the fact that they were hired through affirmative action policies held the weight in the their self-perceptions. 
Heilman, Block, and Lucas (1992) looked at perceptions of affirmative action hires from a different angle, that of the minority individuals' peers. The research evaluated the effect that job sex-type (strongly male or slightly male) and hiree (man, woman, affirmative action woman) had on both the perceived competence of and the adjectives associated with the minority hirees. The results demonstrated that not only were affirmative action women deemed to be less competent than men for the strongly sex-typed job, but also for the slightly sex-typed job. In addition, women with the affirmative action label were rated as lower in competence for both positions than women without the label. Affirmative action women were also deemed to be significantly more passive and more impotent than both men and nonlabeled women. Similar results were produced in the field. Heilman et al. (1992) feel that such findings confirm that a stigma of incompetence is associated with the label of affirmative action.

\section{Devaluation of Stereotypical Minority Work}

Minorities are hurt in two ways by beliefs that particular jobs are associated with the characteristics of a majority subgroup. First, as previously discussed, when minorities enter a traditionally majority field, they are expected to perform poorly. Second, when a minority subgroup predominates in the field, the value of such positions decreases. For example, when women enter traditionally male-dominated positions, the prestige of those jobs falls. In contrast, when males enter stereotypically female positions, the associated prestige of the field rises (Gutek \& Cohen, 1987).

It has actually been shown that men in female fields move up more quickly than comparative females--the glass elevator effect (Williams, 1992). Baron and Newman (1990) note that the positions in which women and minorities form the majority also receive fewer rewards than do similar positions in which males and whites make up the majority. This finding holds true even when skill differences, working conditions, and labor market factors are taken into account.

Baron and Newman (1990) evaluated the effects that sex composition and race composition have on the perceived job worth of civil service positions. The results demonstrated that jobs where females and minorities were high in number were deemed to be substantially lower in worth. However, positive findings were found in that jobs that have been revised recently have incorporated some of the pay equity concerns for females. The influence of union membership was noted as a positive influence on the application of comparable worth policies. Apparently, the unions give great emphasis to females' concerns and have a large voice in the revamping of women's positions in organizations where they have female members.

Pfeffer and Davis-Blake (1987) provided further evidence regarding the devaluation of stereotypical work. The research investigated the relationship between the proportion of women in the field of college administration and the salaries earned by members of the field. An inverse relationship was found between increasing numbers of female college administrators and the salaries of both the men and women in the discipline. Freedman and Phillips (1988) feel that such findings point to the tenet that when work starts to be defined as "womens' work," the associated value of the work will decrease monetarily. Pfeffer and 
Davis-Blake (1987) then point to the frequent finding that as the value of the work decreases, more women are likely to enter the field--further exacerbating the problem.

Arguments based on supply and demand offer an alternative explanation for the devaluation of jobs as proportions of women and minority incumbents grow. Falling barriers to the entrance of women and minorities into an occupation increases the supply of well-qualified applicants and decreases the compensation required to obtain quality. Baron and Newman (1990) argued that neither "the market" nor "devaluation" alone shape the worth of jobs. In their investigation of the effects of demographic composition on normative pay rates attached to a given job, the focus was on the prescribed pay rates for positions, not on incumbents' average wages. The authors' hypothesized that factors in addition to demographic composition affect pay rates, and they controlled for age of the job, union representation and activism, ambiguity of performance criteria, and uniqueness (idiosyncracy) of the job. They found that work done disproportionately by women and minorities is devalued most in positions that are older, not represented by activist unions, have ambiguous performance criteria, or are most generic across organizational settings.

Jacobs' (1992) study of changes in the sex gap in managerial wages found that the gap is narrowing as the number of women managers grows. Using the 1970 census data and the 1988 Current Population Survey data, Jacobs found modest declines in the extent of industrial and occupational sex segregation, and a substantial increase in the chances of men and women sharing the same occupational specialty. While women managers still have a long way to go before the wage gap is closed, the narrowing of the gap does coincide with a substantial rise in the number of female managers.

Noting that his findings contradict those of Pfeffer and Davis-Blake (1987), Jacobs suggests that the different findings may relate to differences in methodology and focus, with his study being much broader in scope and less detailed in measures. He also argues, however, that explanations that rely on the devaluation of stereotypical work to explain wage. disparities may oversimplify the relationship between gender/minority representation and wages, given current political, cultural, and social forces. Federal EEO legislation, the expanding numbers of female MBAs, and the rise of aspirations and expectations, will influence the relationship between the gender/minority composition of the workforce and wages.

\section{Summary}

A natural tendency exists to categorize and stereotype people who are different. Beliefs about behavioral requirements for success in traditionally male dominated roles such as that of manager reflect the gender role stereotype of the male. Stereotypically female behavior patterns are deemed to be inconsistent with the model of the successful male manager. The perceived lack of fit between the female's category and her managerial occupation may place a woman manager in a cruel bind. The prescriptive stereotype dictating that a woman should be, for example, passive and sensitive, conflicts with the model of the successful manager, who should be competitive and independent. 
The disparity between gender role expectations and job role expectations may be greater when tokenism exists. By definition, tokens stand out, making the characteristics of the token's stereotype more salient. Tokens are judged to be less qualified and have less potential than their majority counterparts. As a result, success is more likely to be attributed to favored treatment due to the token's gender or race than to his or her accomplishment. Similarly, affirmative action hires are presumed to be incompetent, and the success of individuals classified as such is attributed to factors other than ability or performance.

Because tokens are presumed to be incompetent, they are held to a higher standard of performance. Both traditional and nontraditional managers report that women and minority managers must work harder to prove themselves than white male managers. In addition, mistakes made by women and minorities receive greater attention than those made by white males. If a "token" manager does not meet performance standards, the stereotype of incompetence among the token's group is reinforced. This can lead to additional pressure on the token manager, who feels responsible for the reputation of his or her group.

Stereotypes and biases are most likely to influence performance evaluations when evaluative criteria are ambiguous, when members of the minority group are few in number, and when information about the individual is limited. In such cases, stereotypes can provide structure and meaning. Familiarity with the individuals being evaluated, specific job-related evaluative criteria developed to minimize subjectivity and bias, and training in evaluation procedures are among the contextual factors that may override stereotypes. Such measures may only provide partial solutions, however. According to Freedman and Phillips (1988), not only have individuals been found to hold on to biased views upon receiving conflicting performance information, but managers are often forced to make decisions without complete performance information. 


\section{INDIVIDUAL FACTORS AND GROUP DIFFERENCES}

This section examines subgroup differences that might impede the career progression of women and minorities. Performance on employment tests, education level, amount and types of experience, willingness to relocate, family care responsibilities, degree of job commitment, and desire for advancement are individual characteristics that are related to managerial success (Howard, 1986; Howard and Bray, 1988; Morrison, 1992; Merit Systems Protection Board, 1992). We examine the evidence that deficiencies among minorities and women in one or more of these areas limit their advancement, thereby contributing to the glass ceiling.

\section{Employment Test Performance}

An effective personnel system supplies a high quality work force. Recruiting activities attract high quality recruits, and valid hiring and promotion screens identify high performers for placement in entry- and higher-level jobs. The Civil Service Reform Act of 1978 requires that the Federal personnel system supply not only a competent work force, but also a representative one (Merit Systems Protection Board, 1992). Some would suggest that it is difficult to achieve both quality and representativeness.

Differences in performance on cognitive ability tests used in employment have been found between some racial/ethnic groups using a variety of measures. To the extent that cognitive measures are used to select employees, differential performance may limit the number of minorities in the pool of candidates that would otherwise be available for promotion. Assessment centers have been widely used to select individuals for entry- and higher-level management jobs; thus, the review includes research on the validity and faimess of assessment centers for women, blacks, and Hispanics. This discussion ends with a review of alternate employment/promotion screens that can promote both quality and representativeness.

Test Validity and Fairness. The concepts of validity, differential validity, and test fairness are key issues in discussions of employment testing of underrepresented groups. Validity has been defined as "the degree to which inferences from scores are justified or supported by evidence" (Society for Industrial and Organizational Psychology, Inc., 1987). Differential validity occurs when the validities for different subgroups are significantly different from one another. This might occur, for example, when an employment screen is a strong predictor of performance for one subgroup but not for another. Test fairness/bias is most frequently defined in terms of the regression model (Cleary \& Hilton, 1968). Test bias exists when the use of a predictor results in either under- or over-predicted criterion performance for a particular group. For example, a test is biased if it predicts lower average levels of job performance for a minority group than it actually achieves.

Meta-analytic studies by Boehm (1972, 1977), Katzell and Dyer (1977), Schmidt, Berner, and Hunter (1973), and Schmidt, Pearlman, and Hunter (1980) indicate that for employment tests, differential validity by racial subgroups (i.e., blacks, Hispanics, and whites) occurs no more frequently than would be expected by chance. With respect to gender differences, Schmitt, Mellon, and Bylenga (1978) analyzed more than 6,200 validity 
coefficients for male-female pairs. Schmitt et al. concluded that firm conclusions could not be drawn about gender differences since some of the studies from which the validity coefficients were collected had small sample sizes. Regarding test faimess, the results of a large number of studies clearly indicate that lower test scores by whites, blacks, and Hispanics are accompanied by lower job performance. These results show that test bias, using the standard definition of test faimess, is not a pervasive problem (Schmidt, 1988). However, freedom from test bias does not ensure proportional hiring rates as a result of test use.

Low test scores on valid tests are associated with low levels of job performance for all applicants, regardless of subgroup. Differences in mean predictor scores across subgroups may present a preliminary barrier to the hiring of minorities and women to the extent that tests exhibiting this property are used. A lower hiring rate among these populations as a result of differential test score performance is referred to as "adverse impact."

Cognitive Ability Tests. With respect to measures of general intelligence, mean test score differences between males and females have been found, however, they are generally small and of little practical significance (Department of Defense, 1982). For example, Bennett, Seashore, and Wesman (1973) found that females performed better than males on measures of perceptual speed and accuracy; males performed better than females on measures of spatial ability and mechanical aptitude. Measures of numerical and verbal reasoning indicated similar scores by males and females.

The Profile of American Youth project conducted by the Department of Defense (1982) found racial/ethnic group differences in specific cognitive abilities. Whites scored consistently higher than blacks and Hispanics on all subtests of the Armed Services Vocational Aptitude Battery (ASVAB). The largest differences occurred with the Word Knowledge subtest. The mean subtest scores did not differ much between the black and Hispanic groups; however, Hispanics scored consistently higher than blacks on all subtests.

Degree of proficiency in the English language may account for some of the differences in test scores among Hispanics and whites. Ramos (1981) gave Hispanic applicants for operator/clerical jobs a choice of receiving Spanish or English instructions for a nonverbal test battery. Although 94 percent of the Hispanic sample noted that they were bilingual, only 29 percent requested Spanish instructions. Those who indicated such a preference were allocated to two groups: one in fact received Spanish instructions and the other received instructions in English. Spanish instructions resulted in a small but significant gain in scores. Interestingly, the test performance of Hispanics who preferred English was substantially higher than that of the Spanish-oriented group. Ramos attributed this finding to the fact that the English-oriented group was, for the most part, educated in the United States.

Differences between whites and blacks have been found consistently on measures of cognitive ability and general intelligence (e.g., Humphreys, 1992). A recent view of these findings proposes that the racial/ethnic group classifications are simple categorizations that do not really explain the test score performance differences, rather, differences in culture may affect the scores (Helms, 1992). That is, blacks are exposed to a different culture than whites and, therefore, score lower on tests that presumably have been developed and normed based on the predominantly white (or Eurocentric) culture. Others have attributed lower scores to 
education and background (Howard \& Bray, 1988; Ramos, 1992). Regardless of the cause. the research on test faimess, discussed above, demonstrates that lower scores on valid cognitive abilities tests predict lower levels of job performance.

Assessment Center Performance. Assessment centers have been used extensively to assess managerial potential since the mid-1960s. Assessment centers consist of managerial work samples such as in-baskets, leaderless group discussions, and role plays. The assessment center method allows candidates multiple opportunities to demonstrate their ability using multiple techniques as evaluated by multiple assessors.

Assessment centers have been found to be equally predictive of managerial job performance for males and females. Moses and Boehm (1975), for example, found that the success rate for women is comparable to that of men. Ritchie and Moses (1983) found that potential ratings based on assessment performance were similarly distributed for men and women. They also found similar relationships between ratings on specific performance dimensions and the progress of males and females in their performance. Ritchie and Moses concluded that differences in management potential are due primarily to individual differences, not to sex differences. Huck and Bray (1976) also found that the assessment center process was equally fair and valid for white and black females. The overall ratings were significantly correlated with supervisory ratings of job performance and potential for advancement.

Ramos (1992) found that performance in an entry-level assessment center predicted progress for Hispanics as well as for whites. However, the measure of verbal and quantitative ability used in this assessment center showed significant differences between the Hispanic and white groups, with Hispanics scoring lower on both subscales. Ramos cautioned that the large difference between the sample sizes (i.e., whites $=32,948$ and Hispanics $=546$ across an 18year time span) may have accounted for the statistically significant finding.

An extensive longitudinal study of managerial characteristics, career experiences, and associated career progress was reviewed in a recent book by Howard and Bray (1988). They reviewed two longitudinal studies conducted at AT\&T--the Management Progress Study begun in 1956 and the Management Continuity Study begun in 1977. Entry-level managers (new college hires and internal non-management candidates for supervisory positions) underwent an extensive assessment process, including simulation exercises, cognitive ability tests, and personality, interest and background assessments.

Howard and Bray (1988) concluded that there were some trivial differences between men and women, but "on no important dimensions did they [women] come up short" (p. 417). They reported that due to some of the personality differences that exist between men and women, women may be at a disadvantage in the higher levels of management where "job roles place less emphasis on individual production and more on exerting power and influence over others" (p. 418). Still, Howard and Bray did indicate that such differences were decreasing over time.

With respect to racial/ethnic group differences, Howard and Bray (1988) indicated that of all the assessment center measures, the cognitive ability factor showed the greatest 
discrepancies among blacks and whites, while measures of interpersonal skill showed very few such differences. Blacks also lagged behind whites on all measures that made up the administrative ability factor. Hispanics and whites had nearly identical scores on the administrative ability factor, and Hispanics scored in between whites and blacks on the cognitive ability factor. Although Hispanic scores on the interpersonal ability factor did not differ significantly from black and white scores, the mean score for Hispanics tended to be lower due to low peer ratings for Hispanic women (one of the measures contributing to this factor). These lower ratings were attributed to the reticence of the Hispanic women to speak out in group exercises.

Assessors also assigned candidates an overall rating reflecting potential for success at middle management. Almost 50 percent of the Hispanic and white participants in the Management Continuity Study were judged to be qualified for middle management, whereas only 25 percent of the blacks were deemed qualified. The authors qualified the differences by noting that although the majority of the candidates had college degrees (the majority of which were advanced degrees), family and educational backgrounds were different among the racial subgroups-with whites having the greater advantage.

Alternative Employment Screens. The identification of high-quality candidates for hire and promotion requires the use of valid predictors of job performance. Cognitive abilities tests, which typically have adverse impact on minorities but not on women, have been shown to be valid predictors of performance for a range of jobs. However, other valid screens exist that have less adverse impact. Consideration of this property of tests in planning the development and validation of employment screens can limit the extent to which adverse impact is an issue.

Two employment screens that are receiving increased attention of late demonstrate little or no adverse impact: Biodata tests and situational judgment tests. Biodata tests consist of multiple choice items that tap the test takers' background, interests, attitudes, accomplishments, and interests. Biodata is growing in popularity because of its predictive power and low adverse impact (Laurence \& Waters, 1993; Trent, 1993). Situational judgment tests are of more recent origin than biodata. Also called the "low-fidelity simulation," the situational judgment test presents the test taker with a series of situations likely to be encountered on the job. After reading each situation, the test taker chooses the best and worst responses from a multiple choice listing of possible responses. If the best and worse responses agree with those keyed as such by subject matter experts, the applicant receives a score of +2 . If neither choice agrees with the key, the applicant receives a score of -2 . Although relatively new, this test shows promising validities and little adverse impact (Motowidlo, Dunnette, \& Carter, 1990). Finally, recent validation research on the structured interview demonstrates that carefully developed and administered interviews can be strong predictors of managerial success (Harris, 1989).

\section{Human Capital}

When discussing capital, most people think of real estate, small business, and so forth. However, discussions of human capital focus on those things that improve an individual's societal standing, employment position, or career opportunities, for example. Becker (1975) 
described investments in human capital as activities that influence future earnings by increasing personal resources. He suggested that these investments include things such as "schooling, on-the-job training, medical care, migration, and searching for information about prices and incomes" (p. 9). He explained that these self-investments in human capital improve knowledge, skills, and health. Although Becker approached the subject of human capital in broad economic terms, it is useful in helping to explain the differences in progression of gender and racial subgroups within organizations.

A study by Stroh et al. (1992) investigated whether a human capital model could explain gender differences in managerial career progression, including salary progression and geographic mobility. Stroh et al. used a hierarchical multiple regression approach to test whether the inclusion of human capital variables or blocks of variables would provide incremental prediction of salary progression and geographic mobility beyond that afforded by tenure. Indicators of human capital were operationalized as level of education (high school, some college, college graduate, some postgraduate work, masters degree, medical degree, jurists degree, or doctorate), number of exits from the work force (number of times managers left the workforce since they had entered as a full-time worker), and number of company changes since first entering the workforce. After controlling for the effects of tenure, the block of human capital variables accounted for additional variance in salary progression, but not in geographic mobility. Education was the only variable within the human capital variable block that was significant, but there was no significant difference in education between males and females. Additionally, gender accounted for an additional 3 percent of salary progression variance when entered last in the analysis, and an additional 1 percent of the geographic mobility variance. Thus, rates of salary progression were significantly higher for males than for females after accounting for both tenure and human capital.

The Merit Systems Protection Board (1992) reported that experience and education are two of the most important factors in career advancement in the Federal government. It should be noted, therefore, that in the government while education levels of women and men with 10 or fewer years of service are equivalent, 23 percent fewer women than men with between 10 and 20 years of service have a four year degree, and 45 percent fewer women than men with more than 20 years of service have a four year degree. In addition, when experience and education are controlled for, the average pay grade of women is significantly below that of men (Merit Systems Protection Board, 1992).

In summary, these studies indicate that differences in human capital alone do not account for different salary and advancement rates. When variables such as education, tenure, and experience are held constant, females still lag behind males.

\section{Mobility}

Another individual difference variable to which organizations attend is mobility, or one's willingness to relocate geographically. Markham (1987) concluded in a review of mobility research that those who relocate for their own advancement apparently do better than those who do not. Additionally, Markham found that men are not only more likely than women to relocate, but that they are also more willing to do so. Similarly, Federal employees in high grades or with more promotions tend to have relocated geographically more often than 
those in lower grades or with fewer promotions. This is often because of either informal or formal promotional requirements that include experience both in the field and at headquarters locations. While the average number of relocations made by men and women for their careers increases as grade level increases, at all levels women have clearly relocated significantly less often than men. As a whole, 58 percent of men and 48 percent of women surveyed said they would be willing to relocate in order to advance their careers (Merit Systems Protection Board, 1992).

Human capital theory may help explain why relocation represents a barrier to female career advancement. The theory suggests that "workers decide whether to migrate by comparing the short-term and long-term benefits they expect in their present location with those they expect to receive elsewhere" (Markham, 1987, p. 213). Since females are not in the labor force as continuously as males (due to childbearing and/or other family matters), Markham states that this discontinuity can impact skill deterioration and, therefore, further career advancement. Women who work continuously are better paid than women who do not (Suter \& Miller, 1973); however, Markham noted that the cause-effect relationship in these studies is not clear.

Another possible way that human capital theory can help explain gender differences in migration is that families generally move based on the greatest gain for the entire family. The idea is that since males traditionally have the higher paying job of the family, relocations will be based more often on the male's job and not the female's job. Markham (1987) called for more research in this area with studies that include other possible theoretical explanations and associated variables, such as family power theory and role theory.

Family power theory asserts that the family member with the most financial resources maintains the greatest power within the family (Stroh et al., 1992). Therefore, since men have traditionally had the largest percentage of family income, geographic moves for the family have been based on the career of the man. This means that the women typically have made geographic moves favoring the man's career, perhaps thwarting their own career progression. Of course, this theoretical explanation only helps explain the career progression, or lack thereof, for women with families.

In a test of this theoretical explanation, Stroh et al.'s (1992) hierarchical multiple regression approach examined a block of variables measuring work experience and company tenure (to control statistically for any pre-existing differences between the men and women in the sample) followed by a measure of family power and a measure of gender. Salary progression was operationalized as the percentage increase in "salary plus bonus" between that earned in 1989 and that earned in 1984 . Geographic mobility was operationalized as the number of geographic moves made for the company. The family power variable was operationalized as the percentage of family income the individual contributed. Results indicated that while the family power variable significantly increased the prediction of salary progression, it did not increase that of geographic mobility beyond that afforded by the workforce experience block. Entering gender last provided a further significant increment in the prediction of salary progression, but not that of geographic mobility. 
Thus, while family power did account for a significant amount of incremental variance of salary progression beyond that of work experience, gender differences still existed after controlling for the previous two variables. This seems to indicate that family power did not account for all of the gender differences in salary progression. The authors did qualify their results regarding the salary progression measure by indicating that there was no control for starting salary.

Markham, Macken, Bonjean, and Corder (1983) found that women who viewed themselves to be the primary provider were just as willing to move as men in the same situation. The authors also reported that managers view willingness to move as an indicator of ambition and career commitment. Expressing a preference to remain stationary may therefore impact promotability. The Merit Systems Protection Board (1992) report confirmed these findings in that willingness to relocate, whether real or assumed, is perceived to indicate commitment to one's career along with a desire for advancement.

\section{Family Care Responsibilities}

Early research found that women with high levels of conflict between work and family roles tended to experience low levels of job satisfaction (Andrisani \& Shapiro, 1978) and job involvement (Gordon \& Hall, 1974). Some researchers have suggested that since women have not had access to the same rewards that men have, women are likely to have lower levels of commitment to the organization (Epstein, 1975; Aranya, 1986). Commitment is defined as "the relative strength of an individual's identifications with, and involvement in, a particular organization or profession" (Mowday, Porter, \& Steers, 1982, p. 434). Lacking the involvement and commitment of their male counterparts, women are promoted less frequently. Finally, others have asked if women managers are paid less because their workplace goals differ from those of men (e.g., Jacobs, 1992; Jackson, Gardner, \& Sullivan, 1992).

Jacobs (1992) analyzed attitudinal data obtained from the General Social Survey (GSS), a national survey of individuals conducted annually from 1972 through 1989 . This survey asked respondents if they would continue to work even if they could afford not to. Most respondents, regardless of sex and time period, reported that they would continue to work.

Respondents also ranked five aspects of work: high income, job security, short hours, chances for advancement, and meaningful work. Jacobs examined sex differences and trends in these variables and explored their impact on the sex gap in wages. In the 1970s and the 1980 s, both sexes ranked the aspects in the same order, from most to least important: "meaningful work"; "chances for advancement"; "high income"; "no danger of being fired"; and "working hours are short, lots of free time." However, in both time periods the mean ranking for meaningful work was higher for women, while the mean ranking for high income was higher for men. Finally, Jacobs found the preference for meaningful work to be unrelated to wages, but the preference for high wages did improve the prediction equation for wages to a slight but significant extent. Jacobs cautions against overstating the causal impact of values, given the potential reciprocal impact of earnings and other work experiences on values. 
Aranya (1986) investigated differences in the organizational commitment of males and females in the male-dominated profession of accounting. The study looked at the effects that gender, age, tenure, organizational level, professional commitment, overall job satisfaction, and intrinsic and extrinsic need satisfaction had on the organizational commitment of accountants working in professional organizations. The results showed that female accountants are less likely to identify and be involved with organizations than males. However, the variance in organizational commitment explained by sex disappeared when demographic and cognitive-affective variables were controlled. Aranya suggested that as women are relative newcomers to public accounting and their numbers are small, managers may still be prejudiced and believe that women have lower organizational commitment than men. In turn, rewards may be offered disproportionately.

The Merit Systems Protection Board (1992) reported evidence to support Aranya's hypothesis, that women are perceived to have lower organizational commitment than men. Based on survey responses to statements about job commitment, women are in fact as committed as men. In addition, a slightly higher percentage of female survey respondents plan to apply for promotion within the next 3 to 5 years, suggesting equivalent levels of ambition. Finally, performance appraisal ratings show that females are judged to be at least as capable as males by their supervisors.

Despite equivalent levels of commitment and ambition, however, several findings suggested that women have to prove their commitment, while men do not. First, the difference in average promotion rates for women and men is greater for those with 10 or fewer years of experience than for those with 10 to 20 years of experience. The authors suggest that females who have remained in the workforce for more than 10 years have proven their commitment, whereas it is more likely to be presumed that men are committed. The report's authors hypothesize that women in their primary child-bearing years, whether or not they have children, may be seen as less committed because they may yet decide to have children. Finally, focus groups and survey results suggest that women are asked to relocate . less often than are men. As previously discussed, willingness to relocate is seen as an indicator of both career commitment and desire for advancement. As such, decision makers might infer that women are less likely to relocate and are therefore less committed to a managerial career. Consequently, women are offered fewer opportunities to relocate.

Focus group results did indicate that childcare responsibilities affect the amount of time a woman can devote to her job, which in turn affects her perceived job commitment (Merit Systems Protection Board, 1992). A trade-off may actually exist between job accommodations to family life and pay (Jackson, Gardner, \& Sullivan, 1992). In other words, part of the discrepancy between pay and advancement between the sexes may be due to the greater family demands placed on women, and the associated absence from the work force. Jackson et al. found supporting evidence for this hypothesis in an investigation of factors that mediate self-pay expectations, or what one expects to earn, and fair pay standards, or what one perceives to be fair pay for a certain type of work.

Four hundred and forty-seven college seniors responded to questions about their perceptions of fair pay, self-pay expectations, and six factors thought to mediate perceptions about pay. One factor, career paths, included occupational and educational choices made by 
males and females that might influence self-pay expectations, such as plans to continue education, hours per week expected to work, years expected to work, and time out from the work force for child rearing. The only gender difference found on this factor was in time out from the work force for child rearing. Women expected to take more time out from the work force ( 3 years) than did men (1 year). Another factor, job facet importance, included valued job outcomes such as pay, promotion, and interpersonal environment (e.g., friendly coworkers). Women considered personal development opportunities, a pleasant work environment, and job accommodations to family life to be more important than did men. However, there was no difference in the importance that women and men placed on high salary, job advancement opportunities, or basic fringe benefits.

Time out for child rearing was among the significant predictors of self-pay expectations and perceptions of fair pay at career entry. Job accommodations to family life was among the significant predictors of self-pay expectations at career peak, but not of perceptions of fair pay. While men and women value high pay equally, women's lower pay expectations may be partly attributable to the importance they place on job accommodations to family life. One recommendation made by the authors for reducing the gender pay gap involves changing the actual and perceived relationship between job accommodations to family life and high pay so that job accommodations to family life are no longer trade-offs for high pay. The authors conclude that major structural and institutional changes will be needed to accommodate a predominantly female work force, many of whom are heads of households and are likely to demand both job accommodations to family life and high pay.

The greater gender diversity in the work force poses two major challenges to modern employers. The first is ensuring that women's talents and abilities are fully utilized on the job. As women become a larger portion of the work force, maximizing their productivity is essential to competitiveness. The second challenge involves adjusting to the greater family responsibilities of women to ensure that the first challenge is met (Jackson \& Alvarez, 1992).

Since competitive success in the marketplace must ultimately be based on comparative excellence, it is important to look at whether investments made in accommodations to family life hinder, help, or have no effect on the productivity. A recent investigation of "work and family" programs suggests that such programs can improve the productivity and quality of worklife for employees and, therefore, can potentially enhance the recruitment, productivity, and retention of a high-quality workforce (Merit Systems Protections Board, 1991). The study reported that the vast majority of private sector firms and large Federal agencies that sponsor child care programs believe that the benefits of these programs far outweigh their costs. The benefits cited included lower rates of absenteeism, greater stability and loyalty within the work force, improved employee morale, enhancement of the organization's image, improved recruitment and retention of quality employees, less employee stress and distraction, and earlier return of employees from maternity leave back to the workforce. The report also looked at alternative work schedules (AWS) and how effective these programs have been. An evaluation of the Federal AWS program by the Office of Personnel Management showed that the benefits to the government of the flextime and compressed work schedules were significant, when utilized in a proper fashion. Some of the positive benefits of these programs included increased hours of service to the public, reduced employee tardiness and absenteeism, decreased energy consumption in buildings, and enhanced general productivity. 
Discussions of trade-offs between family care responsibilities and job demands inevitably lead to two issues. One is the effect of job accommodations on economic competitiveness. That is, do programs that assist employees with family care responsibilities diminish or enhance organizational productivity? The second issue has to do with pay fairness. Proponents on one side of this issue argue that if women are less productive at work and less able to meet job demands requiring travel and relocation than are men, they should be paid less, regardless of the reason. While the evidence presented by the Merit Systems Protection Board suggests that job accommodations to family life do lead to reduced costs and increased productivity, little is known about how family care programs will affect pay and advancement opportunities for women.

\section{Summary}

A number of subgroup differences potentially contribute to the underrepresentation of women in the higher management and executive levels. With the exception of the topic of employment testing, most of the literature in this section relates to the status of women in management, not to minority status.

The literature on employment testing suggests that adverse impact is not a problem with respect to the performance of women. However, disparities in the proportion of whites and minorities will exist at higher management levels to the extent that hiring and promotion decisions are based on tests that measure cognitive abilities. The use of supervisory and managerial selection tests that have little or no adverse impact should minimize the influence of differences in employment test performance on underrepresentation.

Experience, education, tenure, willingness to relocate, and commitment to the job are all highly related to advancement. However, when these factors are held constant across males and females, females still tend to lag behind males in organizational level and pay. These findings may be due in part to the greater role in family care that women traditionally. have held.

Women tend to be less willing to relocate than men are, and reluctance to relocate is perceived as demonstrating a lack of commitment. Similarly, childcare responsibilities may have a greater effect on the amount of time a woman can devote to the job than men, and this also affects perceived job commitment. Attitudinal measures suggest, however, that women do not differ from men on job satisfaction, job commitment, and ambition. Nevertheless, women may be deemed to be less committed than men, regardless of family responsibilities, and this misperception in turn may reduces opportunities for advancement.

Women do seem to view pay differently from men. While women and men value high pay equally, the lower self-pay expectations of women at career entry and career peak are related to greater child care responsibilities. Different pay expectations may be one factor behind the finding that with all else equal, women are still paid less than men. To the extent that women communicate lower pay expectations to prospective employers, they may actually receive lower pay than men for equivalent work. 
Evidence suggests that job accommodations to family life have a number of organizational benefits, including reduced absenteeism and increased morale and productivity. One would expect that to the extent such programs increase the amount of time women with family care responsibilities can devote to the job, the gender disparity in pay and advancement rates will diminish. 


\section{CONCLUSIONS AND RECOMMENDATIONS}

This section of our report integrates the findings from the literature review with the Army's glass ceiling study. Specifically, we identify the most promising approaches to follow in an empirical study of the glass ceiling. This section also highlights potential methods for overcoming or limiting barriers to advancement for women and minorities. The discussion of research approach and recommendations for improvement follows the outline of major causes: systemic barriers, stereotypes and biases, and individual factors and group differences. We conclude with a discussion of major planning considerations for the study.

Two main approaches were taken in the studies of the glass ceiling reviewed in this report, and our research recommendations include them both. The first, analyses of distributions of women and minorities across management levels relies on the information found in personnel records. Such data can be used to pose the first question any glass ceiling study should address: Does the glass ceiling exist? Dependent variables that might indicate the existence of the glass ceiling include level, average salary, average bonus amount or merit award increase, and promotion rates. Each of these variables can be examined as a function of race and/or sex. Demographic and human capital variables known to be related to compensation, promotion rates, and organizational level, such as age, education level, tenure, and other available measures of experience should be controlled when conducting these analyses. Such analyses should be performed within functional specialties such as career programs, as well as Army wide. Finally, it is important to look at the dependent variables over time to determine the extent to which barriers to advancement have fallen.

The second approach collects attitudinal data from interviews, focus groups and surveys to uncover perceptions of different subgroups regarding specific factors that contribute to advancement and those that act as barriers. Focus groups and interviews provide the initial data, which can then be used to develop survey questions to systematically collect attitudinal data from a broader, more representative sample. Surveys can also be used to collect personal history data not available from personnel data bases.

Our recommendations for practice are based on the variables and results that are under the organization's control. Several of the areas surveyed report tentative or conflicting findings. Nevertheless, certain approaches to reducing barriers to advancement surfaced repeatedly. We present these potential solutions here, and point out where uncertainty exists regarding a solution's benefit.

Implicit in all of our recommendations is the need for high level commitment, education, and effective monitoring systems to assess the impact of interventions. Morrison's (1992) recent treatment of organizational strategies for eliminating barriers to advancement, based on indepth study of the diversity practices of 16 major organizations, gives abundant examples of how high level commitment can be used to promote change in this area.

It is important to note that since organizations are reflections of the society in which they exist, changing emfloyment policies and practices cannot totally solve the problems discussed in this report until society as a whole resolves some of the issues of disparate treatment. As a result, the impact of even the most promising solutions may be limited by 
outside forces. However, changes in organizations to eliminate barriers to advancement may well be a first step towards breaking down these barriers on a societal level.

\section{Systemic Barriers}

Future Research. The search for evidence of systemic barriers would first require looking at the distribution of subgroups, by level, across feeder occupations or job series. The Army may wish to make a more fine-grained distinction between dead end and feeder jobs than did the Merit Systems Protection Board (1992) report, in which Professional and Administrative occupations were seen as the stepping stones to higher level management jobs. The distinction between line and staff jobs, or between dead-end and feeder positions, already may be drawn within the Army. If not, it should be possible to identify a representative sample of high level jobs, and analyze the job assignment history of recent incumbents for each of them. This research will not only lay the groundwork for an analysis of power differences across subgroups, but it could also establish a foundation for a career planning guide for employees who demonstrate the willingness and potential to advance.

Data on individual training history would enable the Army to determine whether subgroup members have differential access to training and development opportunities, particularly of the sort that require nomination or competition to qualify. Differences in the amount and types of training might indicate systemic barriers. If certain courses can be identified as career-enhancing training, analyses of participation rates by race and gender is a first step in detecting differential access across subgroups. We strongly encourage the Army to establish a complete and accurate training information system. Such a database would not only permit the analyses described above, but would also allow central searches for highly qualified individuals who could be encouraged to apply for higher level jobs based on training and experience.

Identifying systemic barriers to advancement requires knowledge of the factors that contribute to successful career advancement. Research conducted in a variety of settings, such as that reviewed in this report, provides a starting point. For example, operational assignments that are challenging and highly visible help develop managerial and executive skills. Data from interviews and focus groups can focus in on the specific career enhancing opportunities available to Army civilians. This knowledge can then be used to develop survey questions to ascertain the extent to which such opportunities are available to members of different subgroups. If certain of these opportunities are formal training courses for which records are kept, the training information system would be a primary data source, as described above.

Focus group and survey data can be used to investigate the extent to which mentor relationships have facilitated the career advancement of minorities, women, and white men, and the extent to which some of the commonly cited problems with mentoring relationships have been encountered by members of any subgroups. With careful planning, the information collected could serve as a needs analysis which can in turn drive the development of future programs. Focus groups and surveys can also be used to assess the extent to which subgroup members perceive that they have access to the information and contacts needed for meeting personal career goals. 
Finally, the survey methodology can be used to determine the extent to which perceptions of systemic barriers vary across subgroups. Recall that in the survey results we reviewed, white males underestimated or did not recognize the barriers that women and minorities face; rather, white males felt that affirmative action had removed the employment barriers. Minorities and women, on the other hand, still perceived significant barriers to advancement. Specific evidence that confirms the existence of different realities and pinpoints areas where the perceptions of underrepresented groups and the majority diverge can form the basis for the development of training, monitoring, and other strategies designed to increase workforce diversity. Survey questions reported by Fine et al. (1990), Merit Systems Protection Board (1992), Fernandez (1981), and Alderfer et al. (1980) provide a starting point for survey construction and research design.

Recommendations for Practice. When systemic barriers exist, minorities and women are excluded from jobs, networks, and developmental opportunities that lead to positions of power. The recommendations for addressing systemic barriers are designed to overcome the limited access to information and opportunity experienced by those who face them.

Identify the factors required to get ahead and then make such requirements explicit. Create career paths so that all who have the interest and ability know what they must do to advance.

Individuals obviously bear some of the responsibility for their own career advancement. However, the efforts of those who are excluded from networks and who therefore lack relevant information might be in vain. To combat this possibility, organizations can make information available to everyone.

Provide managers with the tools, training, and support required to assist with employee career development. Make senior managers accountable for advancing a diverse group of employees.

Incumbent managers need information, training and resources to assist with management development. With such support, managers can be made responsible and held accountable for developing managers. Senior managers with a large number of direct and indirect reports can be made accountable for facilitating the career advancement of a diverse pool of applicants with high potential.

Develop valid methods to identify managerial potential. Encourage high potential minorities and women to move from dead end to feeder jobs.

Providing developmental opportunities can help women and minorities in staff or dead end jobs increase their access to jobs that can lead to advancement. An organization can target high potential women and minorities and place them in the key line jobs that lead to positions in the field of management (Morrison \& Von Glinow, 1990). Valid measures of management potential, however, will increase the probability that those targeted for development and advancement will be successful. 
Modify recruitment practices as needed to ensure a diverse applicant pool for all jobs, particularly for upper level jobs. Monitor the extent to which recruitment strategies yield results.

While informal recruiting channels yield superior candidates, they are likely to exclude women and minorities who do not have access to informal networks. Organizations might broaden the recruiting network by involving the EEO director and minority and women managers in the recruitment process. This is particularly important for higher-level openings.

Kirnan et al. (1989) suggest that by modifying the use of its formal recruiting sources, an organization might reach its affirmative action commitments more effectively. For example, since newspaper advertisements have been shown to produce better quality applicants for some jobs than do employment agencies or school placements, an organization could increase its use of newspaper advertisements over other such formal sources. In general, Kirnan et al. (1989) encourage organizations to assess the potential impact on the protected groups before making changes in recruitment policy.

As recommended by the Department of Labor (1991) companies should make any executive search firms that they employ aware of their equal employment and affirmative action obligations under the law. In the case that such executive recruitment firms fail to submit minority and women candidates, companies should make good faith efforts to broaden their pool of candidates.

\section{Design formal mentoring programs so that they embody as many features of informal mentorships as possible, thereby supporting rather than foreing the mentoring process.}

While abundant evidence suggests that informal mentoring relationships are of benefit to managerial advancement, there is little evidence to support the benefits of formal nentor programs (Chao et al., 1992; Merriam, 1983; Morrison \& Von Glinow, 1990). Given this finding, a number of authors have recommended policies that support rather than force the mentoring process (Kram, 1985).

The literature does not address whether or not formal mentorship programs are required in order for women and minorities to have the same access to mentoring relationships as white males. In the case that formal mentorship programs are needed to help women and minorities get mentors, Chao et al.'s (1992) suggestion to make formal mentorship more like informal mentorship might be beneficial. They state that motivation to participate in a mentorship is critical. To achieve such motivation, management should instill a climate of mutual interest and participation without either obligating or intimidating participation. They suggest this could be achieved by clarifying the purpose of such relationships and by neither promising specific benefits from participating nor disadvantages from not participating. Finally, Chao et al. (1985) suggest that in a formal mentorship program, matching the mentor and protégé on interpersonal factors may yield more effective mentoring relationships.

Training programs that teach persons how to develop their skills in the mentor role and how to be mentored can also be helpful (Morrison \& Von Glinow, 1990). Training can 
help develop an awareness of the benefits of such alliances among potential protégés and potential mentors (Fitt \& Newton, 1981). Finally, training can help mentor and protégé deal with cases where the two are not of the same gender, by encouraging both participants to share the responsibility of behaving professionally, dealing with sexual tensions and fears, dealing with stereotypical male/female roles, and learning to cope with any tensions or rumors that may arise (Fitt \& Newton, 1981; Kanter, 1977).

\section{Monitor and evaluate recruitment processes, career development processes, staffing patterns, and promotions. Audit the diversity within functional organizations, and the diversity of pools of applicants for new jobs or promotions.}

Another way to speed removal of the glass ceiling is to monitor progress and mandate change. The U. S. Department of Labor (1991) states that monitoring for equal access and opportunity, especially as managers move up the corporate ladder to senior management levels where important decisions are made, should be considered either as a corporate responsibility or as part of the planning for developmental programs and policies.

\section{Stereotypes and Biases}

Future Research. While field research on performance ratings reveals very limited race and sex effects in evaluations of perfcrmance, experimental research shows that stereotypes can depress performance ratings, particularly when gender role stereotypes and management style are inconsistent. We expect that evidence of bias would be hard to obtain from operational performance ratings, which are typically characterized by a lack of variance.

The influence of stereotypes and biases can be reflected in perceptions of others' reactions and behavior. For example, the extent to which it is perceived that minorities and women are presumed to be incompetent, feel that their errors receive more attention that those of white males, and that they must work harder to prove themselves, can be assessed through focus groups and surveys.

Recommendations for Practice. The recommendations offered in the preceding discussion of systemic barriers all apply to minimizing the operation of stereotypes in the workplace. To guard further against their influence, we offer the following recommendations:

Ensure that evaluation criteria are job-related, clear and unambiguous, and known to both rater and ratee. Train managers thoroughly in the use of performance evaluation systems and avoidance of rater errors.

In the absence of other information, stereotypes influence our interpretation of the events around us. Objective, standardized, employment systems should produce job-relevant performance information and the evaluation criteria needed to make unbiased judgments. As pointed out by Freedman and Phillips (1988), however, model personnel systems may not solve all of the problems. Individuals have been found to hold on to biased views upon receiving conflicting performance information, and managers are often forced to make decisions without complete performance information. Model personnel systems may go a 
long way towards limiting the influence of stereotypes and biases, particularly when managers must share the rationale for their judgments with employees.

\section{Minimize the effects of tokenism by hiring and placing women and minorities in batches, particularty in functions that traditionally have been dominated by white males.}

Kanter (1977) recommended the hiring and placement of managerial women in batches to avoid tokenism, and extending managerial career paths to traditionally female occupations such as clerical work. New programs are being instituted in some corporations that are aimed at reducing the pressure of being a token. One way to change attitudes, some managers believe, is to create a "mass of women in significant jobs within one part of the company instead of spreading the somewhat few of these women throughout the corporation where each is isolated and scrutinized as the token woman" (Morrison et al. 1987, p. 167). This strategy may not be feasible beyond entry level, where placements are fewer in number. However, minorities and women can be assigned in numbers to committees and task forces, thereby minimizing the effects of tokenism in these settings.

\section{Individual Factors and Group Differences}

Future Research. Experience, education, tenure, commitment to the job, and willingness to relocate have all been found to be predictive of managerial success. Women are less willing to relocate than are men, and greater family care responsibilities may reduce the amount of time a women can devote to the job compared to men.

Information in the personnel data base will permit an examination of the extent to which individual factors are related to differences in promotion rates and organization level. Differences among subgroups in human capital variables, such as education level, training and/or experience, tenure, and number of relocations may partially explain differences in promotion rates and level.

Focus group and survey data can supplement the analyses of personnel data. Items measuring organizational commitment, such as those used by the Merit Systems Protection Board (1992), can be compared across subgroups. Self-report data on the number of times the individual has been asked to relocate can also be collected. Recall that the Merit Systems Protection Board not only found that women relocated less often than men, but also that women were asked to relocate less often than men.

Recommendations for Practice. The recommendations in this section broadly apply to all three of the glass ceiling causes. The first three recommendations, all of which entail some degree of systemic change, are becoming more common in practice to minimize the influence of individual factors on employment and advancement opportunities. The first two reflect the perspective of employers who believe that changes in organizational practices are needed to accommodate increasingly diverse individual needs. The fourth recommendation echoes the cautionary note that is common in the writing of practitioners on the use of training as a diversity management tool. 
Provide nexible work scheduling to accommodate family care responsibilities, thereby minimizing individual conflict between work and family roles.

While females carry the major responsibility for family care, because of the growing numbers of dual career couples, changing values with respect to fatherhood, and expanding elder care demands, work and family role conflict is no longer just a women 's issue (Merit Systems Protection Board, 1991). Benefits packages that accommodate family care responsibilities are becoming more common. Among the examples Dipboye (1987) cited were extended leaves for women managers in the child-bearing years; the creation of parttime, lower-level, and middle-level managerial positions; the elimination of the requirement that a manager relocate geographically as a condition for promotion; day-care arrangements; flexible work schedules; and job sharing for managers. In her review of organizational programs to promote diversity, Morrison (1992) cites specific examples of the latter two. In its review of OPM's activities in this area, the Merit Systems Protection Board (1991) recommended that more be done both within OPM and by individual agencies to accommodate the family care needs of Federal employees.

\section{Examine requirements for advancement to distinguish between absolute requirements for organizational success and preferences, conveniences, and traditions.}

With the changing demographics in the workplace, success is increasingly tied to the organization's ability to attract, retain, and motivate a diverse workforce. A correlate of growing heterogeneity in the labor pool is the tendency of people who are different to resist pressure to conform in order to "fit in," or assimilate into, current corporate cultures. If assimilation requires adhering to rules established by white males, some requirements could be difficult, if not impossible, for women and minorities (Thomas, 1992). This line of thinking has led to the suggestion that organizations determine which requirements for individual success also contribute to organizational success. For example, mobility is frequently described as necessary for the breadth of experience and knowledge of the business required for successful performance as a senior manager. The Merit Systems Protection Board (1992) report pointed out that if mobility is a prerequisite for advancement, then this requirement should be shown to be job-related, as required by equal opportunity legislation. Investigation of job-relatedness may show that the developmental paths for senior management jobs do not require the same degree of geographic mobility as previously assumed, or that the breadth and depth of experience for some jobs can be obtained with less geographic mobility than required for other jobs.

Consider potential adverse impact in developing selection and promotion systems. Identify pools of individuals qualified for promotion, thereby increasing the likelihood that qualified minorities and women will be identified as such when positions become vacant.

The use of selection procedures that are known to be effective predictors of successful performance not only ensures employee quality, but also can serve to minimize perceptions of favorable treatment. That is, when all employees who have been selected/promoted have been qualified by the same screens it is harder to attribute advancement to one's network, race or 
sex. Many management selection and promotion systems are structured to identify a qualified pool of candidates who are then available to be placed as positions become vacant. Consideration of race or sex in addition to other factors, such as functional background and experience, can then enter in to promotion decisions. Selection from a qualified pool ensures that minorities and women who are selected are qualified. Expectations for promotion must be considered, of course, in making decisions about the size of the pool.

\section{Be cautious in the use of training as a solution.}

The literature offers few specific insights into the best training approaches to address glass ceiling issues. It does suggest that training for underrepresented groups may be most useful not in skill-building, but in areas such as career- and self-awareness, mentoring, and leadership development. However, it is important to avoid segregating women or minorities in such training programs so they are not seen as needing special help to become equally qualified (Morrison \& Von Glinow, 1990).

The literature suggests training as a partial solution for a number of glass ceiling issues, including confronting stereotypes (Fernandez, 1981), and creating a pool of skilled mentors, as discussed above. However, we recommend that training be designed and developed with care, as the literature offers little guidance. Training thoughtlessly applied might at worst, make a bad situation worse (Morrison, 1992) or at best be a waste of money. For example, training designed to confront stereotypes might be met with resistance by white males who feel that affirmative action gives women and minorities an unfair advantage. On the other hand, training new male and female management hires might be wasted if the attitudes of younger workers differ from those of older workers.

As Dipboye (1987) pointed out, few attempts have been made to evaluate training programs, as evidenced by the sparsity of evaluation studies in the literature. Given such limited guidance, needs assessment, pilot testing, and evaluation are important steps in determining the value of training as a solution. Finally, Morrison (1992) points out that training alone, in the absence of other supporting interventions, will have a short-term impact. While training and education efforts, thoughtfully designed and implemented, should be a part of any effort to change attitudes or corporate cultures, training by itself cannot support longterm change to eliminate the glass ceiling.

\section{Planning Considerations}

One issue of study design is clear from the literature review: Careful planning will be necessary to effectively research such a complex topic. Before embarking on such a study, we recommend that the Army clearly define the goals of the glass ceiling study. How the results of the study will be used will affect its scope and design.

One factor to be considered is the span of years from which data will be sampled for analyses. Longitudinal analyses are valuable in that they can reveal the changes across time in disproportionate distributions across levels, differences in promotion rates, and so on. By looking at trends across time, the Army can also project the rate at which parity will be achieved in the absence of intervention, as did the Merit Systems Protection Board (1992) in 
their study. Such projections would be valuable input for policy makers who are considering various ways to promote diversity. However, it is important to consider factors that might affect demographic distributions in selecting the time frame for analysis. An obvious factor is the recent reduction in force (RIF), and the impact of RIF regulations on the demographic composition of the work force.

Another major planning consideration involves the subgroups to which the study will apply. Planners should consider the need to conduct several studies in parallel, each treating unique barriers faced by various subgroups. We would expect the existence of a core set of barriers. For example, tokenism is probably experienced by all members of underrepresented groups. However, subsets of non-overlapping barriers exist. For example, barriers related to child and family responsibilities are not as relevant to underrepresented males as they are to all females, regardless of race. Implicit in this recommendation is the need to identify the subgroups of interest. The number of subgroups will affect the sampling, number and composition of focus groups, contents of the survey, and all data analyses.

Not many studies on barriers to management examine employment practices for persons with disabilities. However, in 1986 a study for the International Center for the Disabled was conducted with over 1,000 disabled persons. Survey results indicated that 24 percent of all disabled persons under age 65 work full-time, yet 66 percent of all non-working disabled persons (excluding students) would like to have a job. Forty-seven percent of these individuals find that employers will not recognize that they are capable of doing a full-time job. A 1987 follow-up study detailing employment practices for the disabled established that managers rate disabled persons as better than or as good as their nondisabled counterparts, and 75 percent of managers say that the average cost of employing a disabled person is about the same as that of a non-disabled person. Yet three quarters of managers surveyed believe that disabled persons often encounter discrimination from employers and only one of ten top level managers display an optimistic attitude towards considering them as a potential source of employees.

It seems as though disabled individuals face barriers much earlier in the employment process than do other underrepresented groups. Disabled individuals are not only locked out of management jobs, but out of the job market. This situation is quite different from that examined in the typical glass ceiling study.

The disabled are unique in another way. Unlike the distinguishing features of other underrepresented groups--gender, accent, color--the distinguishing features of this subgroup are large in number. That is, a disability can be manifest in a large variety of ways. The extent to which the variety and severity of disabilities affect the treatment of the disabled in an employment setting is unknown. Given the lack of information on organizational barriers faced by this subgroup, we recommend that the variables included in this part of the study be determined after a more focussed literature search and with abundant input from representatives of the disabled community. 


\section{REFERENCES}

Alderfer, C. P., Alderfer, C. S., Tucker, L., \& Tucker, R. (1980). Diagnosing race relations in management. Joumal of Applied Behavioral Science, 16, 135-166.

Alleman, E., Newman, I., Huggins, H., \& Carr, L. (1986). Are all mentors alike? The impact of race and gender on mentorine relationships. Paper presented at the American Psychological Association National Convention, Washington, DC.

Andrisani, P. J., \& Shapiro, M. B. (1978). Women's attitudes toward their jobs: Some longitudinal data on a national sample. Personnel Psychology, 31, 15-34.

Aranya, N., Kushnir, T., \& Valency, A. (1986). Organizational commitment in a maledominated profession. Human Relations, 35, 433-488.

Baron, J., \& Newman, A. (1990). For what it's worth: Organizations, occupations, and the value of work done by women and nonwhites. American Sociological Review, 55 , 155-175.

Becker, G. S. (1975). Human capital. Chicago: University of Chicago Press.

Bennett, G. K., Seashore, H. G., \& Wesman, A. G. (1973). Manual for the differential aptitude test. New York: The Psychological Corporation.

Blau, F. D., \& Beller, A. H. (1988). Trends in earning differentials by gender 1971-1981. Industrial and Labor Relations Review, 41(4), 513-529.

Boehm, V. R. (1972). Negro-white differences in validity of employment and training selection procedures: Summary of research evidence. Joumal of Applied Psychology, 56, 33-39.

Boehm, V. R. (1977). Differential prediction: A methodological artifact? Loumal of Applied Psychology, 62, 146-154.

Chao, G. T., Walz, P. M., \& Gardner, P.D. (1992). Formal and informal mentorships: A comparison on mentoring functions and contrast with nonmentored counterparts. Personnel Psychology, 45, 619-636.

Clawson, J. G. (1985, April). Is mentoring necessary? Trainine and Development Journal, 37-39.

Cleary, T. A., \& Hilton, T. I. (1968). Test bias: Prediction of grades of Negro and white students in integrated colleges. Joumal of Educational Measurement, 5, 115-124. 
Colwill, N. L. (1987). Men and women in organizations: Roles and status, stereotypes and power. In K. S. Koziara, M. H. Moskow, \& L. D. Tanner (Eds.), Working women: Past. present. and furure (97-117). Washington, DC: The Bureau of National Affairs, Inc.

Dipboye, R. L. (1985). Some neglected variables in research on discrimination in appraisals. As cited in S. H. Oppler, J. P. Campbell, E. D. Pulakos, \& W. C. Borman, Three approaches to the investigation of subgroup bias in performance measurement: Review, results, and conclusions (1992). Joumal of Applied Psychology, 77, 201-217.

Dipboye, R. L. (1987). Problems and progress of women in management. In K. S. Koziara, M. H. Moskow, \& L. D. Tanner (Eds.), Working women: Past. present. and future (118-153). Washington, DC: The Bureau of National Affairs, Inc.

Dreher, G. F., \& Ash, R. A. (1990). A comparative study of mentoring among men and women in managerial, professional, and technical positions. Joumal of Applied Psychology, 75, 539-546.

Dubno, P. (1985). Attitudes toward women executives: A longitudinal approach. Academy of Management Joumal, 28, 235-239.

Eagly, A. H., Makhijani, M. G., \& Klonsky, B. G. (1992). Gender and the evaluation of leaders: A meta-analysis. Psychological Bulletin, 111, 3-22.

Edwards, J. E., Thomas, M. D., \& Burch, R. L. (1992). Hispanic representation in the Federal Government: Lessons from the Navy's equal employment opportunity enhancement research program. In S. B. Knouse, P. Rosenfeld, \& A. L. Colbertson (Eds.), Hispanics in the workplace. Newbury Park, CA: Sage Publications.

Epstein, C. F. (1975). Institutional barriers: What keeps women out of the executive suite? In F. E. Gordon \& M. H. Strober (Eds.), Bring women into management (7-21). New York: McGraw-Hill.

Fernandez, J. P. (1981). Racism and sexism in corporate life. Lexington, MA: Lexington Books.

Fine, M., Johnson, F., \& Ryan, M. (1990). Cultural diversity in the workplace. Public Personnel Management, 19(3), 305-319.

Fiske, S. T., Bersoff, D. N., Borgida, E., Deaux, K., \& Heilman, M. E. (1991). Social science research on trial: Use of sex stereotyping research in Price Waterhouse v. Hopkins. American Psychologist, 46, 1049-1060. 
Fitt, L. W., \& Newton, D. A. (1981, March-April). When the mentor is a man and the protege a woman. Harvand Business Review, 56-60.

Freedman, S. M., \& Phillips, J. S. (1988). The changing nature of research on women at work. Joumal of Manarement, 14, 231-251.

General Accounting Office (1991). Eederal Affirmative Employment: Status of Women and Minority Representation in the Federal Workforce, Report No. GAO/T-GGD-92-2. Washington, DC.

Gordon, F. E., \& Hall, D. T. (1974). Self-image and stereotypes of femininity: Their relationship to women's role conflicts and coping. Joumal of Applied Psychology, 52, 241-243.

Gutek, B., \& Cohen, A. (1987). Sex ratios, sex role spillover, and sex at work: A comparison of men's and women's experiences. Human Relations, 40, 97-115.

Harris, M. M. (1989). Reconsidering the employment interview. A review of recent literature and suggestions for future research. Personnel Psychology, 42, 691-726.

Heilman, M. E., Block, C. J., \& Lucas, J. A. (1992). Presumed incompetent? Stigmatization and affirmative action efforts. Joumal of Applied Psychology, 77, 536-544.

Heilman, M. E., \& Martell, R. F. (1986). Exposure to successful women: Antidote to sex discrimination in applicant screening decisions? Organizational Behavior and Human Decision Processes, 37, 376-390.

Heilman, M. E., Martell, R. $\bar{F}$, and Simon, M. C. (1988). The vagaries of sex bias: Conditions regulating the undervaluation, equivaluation, and overvaluation of female job applicants. Oreanizational Behavior and Human Decision Processes, 41, 98-110.

Heilman, M. E., Simon, M. C., \& Repper, D. P. (1987). Intentionally favored, unintentionally harmed? Impact of sex-based preferential selection on self-perceptions and self-evaluations. Joumal of Applied Psychology, 72, 62-68.

Helms, J. E. (1992). Why is there no study of cultural equivalence in standardized cognitive ability testing? American Psychologist, 47, 1083-1101.

Howard, A. (1986). College experiences and managerial performance. Joumal of Applied Psychology Monograph, 71(3), 530-552.

Howard, A., \& Bray, D. W. (1988). Managerial lives in transition: Advancing age and changing times. New York: The Guilford Press. 
Huck, J. R., \& Bray, D. W. (1976). Management assessment center evaluations and subsequent job performance of black and white females. Personnel Psychology, 29, 13-30.

Humphreys, L. G. (1992). Commentary: What both critics and users of ability tests need to know. Psychological Science, 3, 271-274.

Hunt, D. M., \& Michael, C. (1983). Mentorship: A career training and development tool. Academy of Management Review, 8(3), 475-485.

International Center for the Disabled (1986). The ICD Survey of Disabled Americans: Bringine Disabled Americans into the Mainstream, Study No. 854009. New York.

Irons, E. D., \& Moore, G. W. (1985). Black managers: The case of the banking industry. New York: Praeger.

Jackson, L. A., Gardner, P. D., \& Sullivan, L. A. (1992). Explaining gender differences in self-pay expectations: Social comparison standards and perceptions of fair pay. Journal of Applied Psychology, 77, 651-663.

Jackson, S. E., \& Alvarez, E. B. (1992). Working through diversity as a strategic imperative. In S. E. Jackson \& Associates (Eds.), Diversity in the Workplace; Human Resources Initiatives (13-29). New York: The Guilford Press.

Jackson, S. E., Brett, J. F., Sessa, V. I., Cooper, D. M., Julin, J. A., \& Peyronnin, K. (1991). Some differences make a difference: Individual dissimilarity and group heterogeneity as correlates of recruitment, promotions, and turnover. Journal of Applied Psychology, 76, 675-689.

Jacobs, J. (1992). Women's entry into management: Trends in earnings, authority, and values among salaried managers. Administrative Science Quarterly, 37, 282-301.

Jones, E. W., Jr. (1986, May-June). Black managers: The dream deferred. Harvard Business Review, 84-93.

Kanter, R. M. (1977). Men and women of the corporation. New York: Basic Books.

Kanter, R. M. (1979, July-August). Power failure in management circuits. Harvard Business Review, 65-75.

Katzell, R. A., \& Dyer, F. J. (1977). Differential validity revived. Journal of Applied Psychology, 62, 137-145. 
Kiman, J. P., Farley, J. A., \& Geisinger, K. F. (1989). The relationship between recruiting source, applicant quality, and hire performance: An analysis by sex, ethnicity, and age. Perconnel Psychology, 42, 293-308.

Kraiger, K., \& Ford, J. K. (1985). A meta-analysis of ratee race effects in performance ratings. Joumal of Applied Psychology, 70, 56-65.

Kram, K. E. (1985, April). Improving the mentoring process. Training and Development Joumal, 40-43.

Larwood, L., Gutek, B., \& Gattiker, U. E. (1984). Perspectives on institutional discrimination and resistance to change. Group and Organization Studies, 2, 333-352.

Larwood, L., Szwajkowski, E., \& Rose, S. (1988). Sex and race discrimination resulting from manager-client relationships: Applying the rational bias theory of managerial discrimination. Sex Roles, 18, 9-29.

Laurence, J. H., \& Waters, B. K. (1993). Biodata: What's it all about? In T. Trent and J. H. Laurence (Eds.), Adaptability Screenine for the Armed Forces. Washington, DC:

Office of the Assistant Secretary of Defense (Force Management and Personnel), 41-71.

Leinsten, C. (1988). Black executives: How they're doing. Fortune, January 18, 109-120.

Leventhal, G., \& Herbert, H. (1990). Effect of subjects' sex and sex-role attitudes on real and perceived performance using gender-related stimuli with traditional and nontraditional female experimenters. Psychological Reports, 66, 259-266.

Mainiero, L. (1986). Coping with powerlessness: The relationship of gender and job dependency to empowerment-strategy usage. Administrative Science Quarterly, 31, 633-653.

Malveaux, J., \& Wallace, P. (1987). Minority women in the workplace. In K. S. Koziara, M. H. Moskow, \& L. D. Tanner (Eds.), Working women: Past. present. and future (265-298). Washington, DC: The Bureau of National Affairs, Inc.

Markham, W. T. (1987). Sex, relocation, and occupational advancement. In A. H. Stromberg, L. Lombard, \& B. A. Gutek (Eds.), Women and work: An annual review (Vol. 2, 207-231). Newbury Park, CA: Sage Publications.

Markham, W. T., Macken, P. O., Bonjean, C. M., \& Corder, J. (1983). A note on sex, geographic mobility, and career advancement. Social Forces, 61, 1138-1146.

Merriam, S. (1983). Mentors and proteges: A critical review of the literature. Adult Education Quarterly, 33, Spring, 161-173. 
Morrison, A. M. (1992). The new leaders, Guidelines on leadership diversity in America. San Francisco: Jossey-Bass, Inc.

Morrison, A. M., \& Von Glinow, M. A. (1990). Women and minorities in management. American Psychologist, 45(2), 200-208.

Morrison, A. M., White, R. P., Velsor, E. V., \& The Center for Creative Leadership (1987). Breakine the glass ceiling, Can women reach the top of America's largest corporations? Reading, MA: Addison-Wesley Publishing Company, Inc.

Moses, J. L., \& Boehm, V. R. (1975). Relationship of assessment center performance to management progress of women. Joumal of Applied Psychology, 60, 527-529.

Motowidlo, S. J., Dunnette, M. D., and Carter, G. W. (1990). An altemative selection procedure: The low-fidelity simulation. Joumal of Applied Psychology, 75, 640-647.

Mowday, R. T., Porter, L. W., \& Steers, R. M. (1982). Empleyec-Organization Linkages. New York: Academic Press.

Oppler, S. H., Campbell, J. P., Pulakos, E. D., \& Borman, W. C. (1992). Three approaches to the investigation of subgroup bias in performance measurement: Review, results, and conclusions. Joumal of Applied Psychology, 77, 201-217.

Pfeffer, J., \& Davis-Blake, A. (1987). The effect of the proportion of women on salaries: The case of college administrators. Administrative Science Quarterly, 31, 1-24.

Pulakos, E. D., White, L. A., Oppler, S. H., \& Borman, W. C. (1989). Examination of race and sex effects on performance ratings. Joumal of Applied Psychology, 74, 770-780.

Ramos, R. A. (1981). Employment battery performance of Hispanic applicants as a function of English or Spanish test instructions. Joumal of Applied Psychology, 66(3), 291-295.

Ramos, R. A. (1992). Testing and assessment of Hispanics for occupational and management positions: A developmental needs analysis. In X. F. Geisinger (Ed.), Psychological Testing of Hispanics. Washington, DC: American Psychological Association.

Ritchie, R. J., \& Moses, J. L. (1983). Assessment Center Correlates of Women's Advancement into Middle Management: A 7-year longitudinal analysis. Joumal of Applied Psychology, 68(2), 227-231.

Roche, G. R. (1979, January-February). Much ado about mentors. Haryard Business Review, 57(1), 14-28. 
Rosen, B., Templeton, N. C., \& Kichline, K. (1981, December). First few years on the job: Women in management. Business Horizons, 24, 226-229.

Schmidt, F. L. (1988). The problem of group differences in ability test scores in employment selection. Joumal of Vocational Behavior, 33, 272-292.

Schmidt, F. L., Berner, J. G., \& Hunter, J. E. (1973). Racial differences in validity of employment tests: Reality or illusion? Joumal of Apolied Psychology, 58, 5-9.

Schmidt, F. L., Pearlman, K., \& Hunter, J. E. (1980). The validity and faimess of employment and educational tests for Hispanic Americans: A review and analysis. Personnel Psychology, 33, 705-724.

Schmitt, N., Mellon, P. M., \& Bylenga, C. (1978). Sex differences in validity for academic and employment criteria, and different types of predictors. Joumal of Apolied Psychology, 63, 145-150.

Sheehy, G. (1976). Pascages: Predictable crises of adult life. New York: E. P. Dutton and Co.

Sigelman, L., Milward, H. B., \& Shepard, J. M. (1982). The salary differential between male and female administrators: Equal pay for equal work? Academy of Management Joumal, 25(3), 664-671.

Society for Industrial and Organizational Psychology, Inc. (1987). Principles for the validation and use of personnel selection procedures (3rd ed.). College Park, MD.

Stroh, L. K. , Brett, J. M., \& Reilly, A. H. (1992). All the right stuff: A comparison of female and male managers' career progression. Joumal of Applied Psychology, 77(3), 251-260.

Suter, L. E., \& Miller, H. P. (1973). Income differences between men and career women. American Joumal of Sociology, 78, 963-974.

Tajfel, H. (1982). Social psychology of intergroup relations. Annual Review of Psychology, 33, 1-39.

Terborg, J. R. (1977). Women in management: A research review. Joumal of Applied Psychology, 62, 647-664.

Trent, T. (1993). The Armed Services Applicant Profile (ASAP). In T. Trent and J. H. Laurence (Eds.), Adaptability Screenine for the Armed Forces. Washington, DC: Office of the Assistant Secretary of Defense (Force Management and Personnel), 71-100. 
Tsui, A. S., \& Gutek, B. A. (1984). A role set analysis of gender differences in performance affective relationships, and career success of industrial middle managers. Academy of Management Joumal, 27, 619-635.

Thomas, D. A., \& Alderfer, C. P. (1989). The influence of race on career dynamics: Theory and research on minority career experiences. In M. B. Arthur, D. T. Hall, \& B. S. Lawrence (Eds.), Handbook of Career Theory (133-158). Cambridge, England: Cambridge University Press.

Thomas, R. R., Jr. (1992). Managing diversity: A conceptual framework. In S. E. Jackson \& Associates (Eds.), Diversity in the Workplace: Human Resources Initiatives (306-317). New York: The Guilford Press.

U.S. Department of Defense (1982). Brofile of American Youth: 1980 Nationwide Administration of the Armed Services Vocational Adtitude Battery. Washington, DC: Office of the Assistant Secretary of Defense (Manpower, Reserve Affairs, and Logistics).

U.S. Department of Labor (1991). A report on the glass ceiling initiative. Washington, DC.

U.S. Department of Labor (1992). Pipeline of progress. A status report on the glass ceiling. Washington, DC.

U.S. Merit Systems Protection Board (1991). Balancing work responsibilities and family needs. Washington, DC: Office of Policy and Evaluation.

U.S. Merit Systems Protection Board (1992). A question of equity: Women and the glass ceiline in the federal government. Washington, DC: Office of Policy and Evaluation.

Valerio, A. M. (1990). A study of the developmental experiences of managers. In K. E. Clark, \& M. B. Clark (Eds.), Measures of Leadership (521-534). West Orange, NJ: Leadership Library of America, Inc.

Westman, M., \& Etzion, D. (1990). The career success/personal failure phenomenon as perceived in others: Comparing vignettes of male and female managers. Joumal of Vocational Behavior, 37, 209-224.

Williams, C. L. (1992). The glass escalator: Hidden advantages for men in the "female" professions. Social Problems, 39, 253-267. 


\section{Appendix A}

\section{Highlights of Civil Rights Legislation and Case Law}

In 1991, the Glass Ceiling Act, contained in Tite II of the 1991 Civil Rights Act, was established for two main purposes: to establish a Glass Ceiling Commission that will terminate in 1995; and to establish an annual award for excellence in promoting a more diverse skilled workforce at higher levels. The purposes of the Glass Ceiling Commission are to focus greater attention on the importance of eliminating artificial barriers to the advancement of women and minorities to management and decision-making positions and to promote workforce diversity. The commission is chaired by the Labor Secretary and consists of two senators, two House representatives, 21 presidential appointees, and 10 House and Senate appointees. The Commission is required to examine and make recommendations concerning preparations and opportunities for advancement by women and minorities, and employers' practices and policies regarding such issues. This Act constitutes the first large scale effort by the government to examine the barriers faced by women and minorities. Although the Glass Ceiling Act does not itself generate change in legislation, it is part of the 1991 Civil Rights Act which does generate legislative change in regard to recent case law.

Historically, legislation concerning discrimination in the workforce began with the Civil Rights Act of 1964. Title VII of this Act states that it is an unlawful employment practice to discriminate on the basis of race, color, sex, religion or national origin. At this time, sex was included with the other characteristics by some members of Congress only to ensure that the bill would not be passed. However, the bill was passed and protection against discrimination for women became law. Provisions of the Act include the granting of power to the courts to decide upon equitable relief when employers are proven to have intentionally engaged in prohibited practices. Equitable relief included restoring individuals to positions they would have occupied had they not been subject to discrimination, backpay, and other forms of equity deemed appropriate by the courts. In addition, the Act established the Equal Employment Opportunity Commission (EEOC) which was given the power to investigate and file charges against alleged violators, but not to bring suit directly against employers. However, the EEOC could provide informal conciliation to settle disputes.

In 1972, the Equal Employment Opportunity Act was passed to give enforcement power to the EEOC such that the EEOC (as well as a private individual) could prevent unlawful employment practices by bringing suit directly against an offending employer. The amended Act then functioned in two ways; first, to provide equitable relief to the individual(s) discriminated against, and, second, to eliminate and deter workplace discrimination by forcing companies to provide relief to the individuals.

From 1972 until 1991, the interpretation of Equal Opportunity regulations has developed not as a result of the activities of various federal agencies, but as a direct consequence of highly significant federal cour interpretations on a variety of cases. For example, in the landmark case of Griggs vs. Duke Power Company, 401 U.S. 424 (1971), the Supreme Court ruled that it is the results and consequences of an employer's actions --not the intent--that determine whether the employment practice is discriminatory. Case law also 
stated that any employment practice or policy which has a disparate impact on members of a protected class or which perpetuates the effect of previous discriminatory practices is unlawful. The only exception to this is proof that such a policy or practice is required by "business necessity." A practice is considered to be required as a business necessity only if it is valid and job-related. It is the emplover's burden to prove beyond any reasonable doubt that such a policy is necessary for the safe and efficient operation of the business.

However, a number of Supreme Court decisions from 1989 to 1991 reversed some of the above decisions. During this period it became increasingly difficult for complainants to win or even bring suits alleging discrimination. Many critics said that the Supreme Court was ignoring Congress's overall purpose to eradicate discrimination. Examples of the significant cases and decisions include Wards Cove Packing Co. vs Atonio, Patterson vs. McLean Credit Union, and Price-Waterhouse vs. Hopkins. In the Wards vs. Atonio case, the cour made it the responsibility of the employee to prove that an employment practice adversely affected protected classes without any "business necessity." In the second case, the court decision limited the coverage of a key race discrimination statute to hiring only (not to promotion or any other practice). Based on this decision, approximately 200 claims of harassment, discriminatory firing, or other employment practices were dismissed in the following 8 months. In the infamous Price Waterhouse case, the Supreme Court ruled that an employer could avoid liability of an intentionally discriminatory employment decision, as long as the decision is partially motivated by legitimate reasons, and the employer can show that the same decision would have been made without taking into account the discriminatory reason(s).

The Civil Rights Act of 1991 ended two years of bitter debate concerning employment discrimination, overturning in whole or in part seven decisions handed down by the Supreme Court that had reduced complainants rights. Specifically, the new legislation overrules the Wards Cove decision, reinstating the previous legal standard that once disparate impact is shown by the complainant, the employer has the burden to prove that the challenged employment practices are "job related for the position in question and consistent with business necessity." The Act also makes it clear that all discriminatory employment practices and policies are covered by law. In reference to the Price Waterhouse decision, the 1991 Act provides that it is unlawful to rely on race, sex, or any prohibited factor in motivating a job decision, even if other legal factors might also justify the employment decision or practice. Therefore, intentional discrimination is unlawful in every case.

The Civil Rights Act of 1991 also expands the remedies available to victims of discrimination.' Historically, under the 1964 Civil Rights Act, victims of discrimination (based on race, color, national origin, religion, or sex) could recover back pay, employment or reinstatement, and other forms of injunctive relief, but not compensatory or punitive damages. However, the Supreme Court ruled that under Section 1981 of the 1866 Civil Rights Act, victims of discrimination due to race or ethnicity could receive compensatory or punitive damages. Since the 1866 Civil Rights Act did not include other protected groups, they were

1 The remainder of this section was extracted from Vinick, S. (undated). A summary of the 1991 Civil Rights Act. Washington, DC: Lawyers' Committee for Civil Rights Under Law. 
not included in the ruling. In 1991, the Americans with Disabilities Act resulted in allowing victims of discrimination based on disabilities to recover backpay, employment, or other forms of injunctive relief, but not compensatory or punitive damages.

The Civil Rights Act of 1991 seeks to allow all victims of intentional discrimination to receive compensatory, and in certain cases, punitive damages. This includes victims discriminated against based on race, color, national origin, ethnicity, religion, sex, and disabilities. However, compensatory and punitive damages are subject to combined caps ranging from $\$ 50,000$ to $\$ 300,000$ depending on the size of the firm. The damage caps have been criticized because victims of discrimination based on race or ethnicity can file under Section 1981 with no damage caps, while victims discriminated against based on sex, religion, or disability must file under the 1991 Act with damage caps. Critics of the damage caps contend that even victims of discrimination will be treated disparately. Defendants of the damage caps contend that their purpose is to limit the incentives for suing individuals and for lawyers to pursue claims that could result in large sums of money being awarded.

Other new laws enacted under the 1991 Civil Rights Act include the right of any person filing a claim under the Act to demand a jury trial for claims in which compensatory or punitive damages are sought, and the right of employees in the federal sector to sue for compensatory damages. 